NBER WORKING PAPER SERIES

\title{
401(k) MATCHING CONTRIBUTIONS IN COMPANY STOCK: COSTS AND BENEFITS FOR FIRMS AND WORKERS
}

\author{
Jeffrey R. Brown \\ Nellie Liang \\ Scott Weisbenner \\ Working Paper 10419 \\ http://www.nber.org/papers/w10419 \\ NATIONAL BUREAU OF ECONOMIC RESEARCH \\ 1050 Massachusetts Avenue \\ Cambridge, MA 02138 \\ April 2004
}

The views expressed in this paper are those of the authors and not necessarily those of the Federal Reserve Board. We thank Eric Richards, Thomas McAndrews, and Aldo Rosas for exceptional research assistance, and Annika Sunden and Alicia Munnell for providing the age-earnings profiles used in this paper. We also thank Bill Even, David Laibson, Olivia Mitchell, Steve Utkus and seminar participants at the University of Illinois and the Federal Reserve Board for their comments and constructive suggestions. The views expressed herein are those of the author(s) and not necessarily those of the National Bureau of Economic Research.

(C2004 by Jeffrey R. Brown, Nellie Liang, and Scott Weisbenner. All rights reserved. Short sections of text, not to exceed two paragraphs, may be quoted without explicit permission provided that full credit, including (C) notice, is given to the source. 
401(k) Matching Contributions in Company Stock: Costs and Benefits for Firms and Workers Jeffrey R. Brown, Nellie Liang, and Scott Weisbenner

NBER Working Paper No. 10419

April 2004

JEL No. G11, J30, J32

\section{ABSTRACT}

This paper examines why some employers provide matching contributions to $401(\mathrm{k})$ plans in company stock and explores the implications of match policy for employee retirement wealth. Unlike stock option grants to non-executives, a firm's decision to match in company stock does not appear to be strongly correlated with cash flow or with measures of the benefits of aligning incentives of employees and employers. Rather, we find evidence that firms are more likely to provide the match in company stock if firm risk is low (i.e. lower stock price volatility and lower bankruptcy risk) and employees are also covered by a defined benefit plan. These findings suggest that firms consider the retirement security of their workers in making the match decision, either because firms want to minimize the risk of violating their fiduciary responsibility or because employees more fully value company stock at companies with lower firm-specific risk. Evidence also indicates that firms may want to match in company stock to boost employee ownership, perhaps to help deter takeovers, or because of the tax advantages for dividends on the company stock match. Simulation results suggest that sufficiently risk-tolerant individuals actually prefer a 401(k) plan at a company with a company stock match to a plan at a company with an unrestricted match, unless the equity premium is reduced substantially.

\begin{tabular}{|c|c|c|}
\hline Jeffrey R. Brown & Nellie Liang & Scott Weisbenner \\
\hline 340 Wohlers Hall & Federal Reserve Board & 340 Wohlers Hall \\
\hline University of Illinois at Urbana & $20^{\text {th }}$ and Constitution Ave NW & University of Illinois at Urbana \\
\hline Champaign & Washington, DC 20551 & Champaign \\
\hline $\begin{array}{l}\text { Champaign, IL } 61820 \\
\text { and NBER } \\
\text { brown } @ \text { nber.org }\end{array}$ & nliang@frb.gov & $\begin{array}{l}\text { Champaign, IL } 61820 \\
\text { and NBER } \\
\text { weisbenn@uiuc.edu }\end{array}$ \\
\hline
\end{tabular}




\section{Introduction}

Company stock in $401(\mathrm{k})$ plans has been the subject of intense scrutiny by policy makers over the past several years. In the wake of high profile corporate bankruptcies for companies that had a large fraction of $401(\mathrm{k})$ plan assets invested in company stock, numerous lawmakers began calling for new regulations and restrictions on company stock ownership in 401(k) plans. ${ }^{1}$ In part motivated by these events, a growing number of academic papers have begun to examine assets in 401(k) plans in general, and the effects of employer match policy in particular. Recent research papers have examined the relative adequacy of retirement wealth for defined benefit versus defined contribution plans (Samwick and Skinner, 2003; Even and McPherson, 2003a), the importance of plan design and employee inertia (Choi, Laibson, Madrian, and Metrick, 2001; Agnew, Balduzzi, and Sunden, 2003), the effect of 401(k) match policy on employee purchases of company stock (Bernartzi 2001; Liang and Weisbenner, 2002), and the role of company stock in 401(k) portfolios (Mitchell and Utkus, 2004; VanderHei, 2002).

Notably absent from this literature is an understanding of why companies choose to provide their match in company stock in the first place. ${ }^{2}$ After all, standard portfolio theory suggests that there are potentially large welfare costs to forcing employees to hold part of their portfolio in company stock (Meulbroek, 2002). Presumably, there must be some benefits of providing a match in company stock to offset these potential welfare costs, or else profitmaximizing companies would not compensate their employees in a form that may not be valued fully. Indeed, there are a number of potential benefits to a firm from providing a match in company stock. Specifically, a match in company stock has lower expenses than other investment options, can free up cash for other uses, boosts employee ownership, and potentially reduces corporate taxes if the firm pays dividends. Firms that match in company stock may also be those where the cost to employees of being concentrated in company stock is the lowest. That is, the costs of matching in company stock could be lower at firms that also provide other retirement benefits or have lower stock price volatility. We test these alternative hypotheses,

\footnotetext{
${ }^{1}$ For example, Senators Boxer and Corzine introduced legislation that would place a 20 percent cap on the share of 401(k) plan balances that could be invested in company stock. (http://www.kcstar.com/item/pages/business.pat,business/3acd380f.c18,.html)

${ }^{2}$ In a paper written concurrently with this one, Even and Macpherson (2003b) examine why company stock is held in defined contribution plans, but do not specifically focus on match policy. Our study focuses on why, conditional on offering company stock as an investment option, firms decide to offer a match in company stock. Most large publicly-traded corporations offer company stock as an investment option while approximately one-third require that the match be held in company stock (Profit Sharing / 401(k) Council of America, 2002).
} 
providing the first evidence of how a company's decision to provide its match in company stock or to offer an unrestricted match is affected by company characteristics.

Using a sample of all publicly traded companies that filed an 11-k statement from 1994 to $2001,{ }^{3}$ we find little evidence that firms provide the employer match in company stock because of cash flow constraints or to increase employee ownership to better align incentives. This is in contrast to the literature on stock options to non-executive employees, which finds that these factors are important determinants of options grants (Core and Guay, 2001).

Instead, we find that less risky firms, in terms of lower stock price volatility and a lower expected bankruptcy rate, are more likely to provide the employer match in company stock. In addition, we find that firms that have a defined benefit plan are significantly more likely to provide the match in company stock, particularly if the match is small relative to employee contributions and hence employer contributions to the 401(k) plan are a less important source of wealth for employees. These findings suggest that firms do take into account the effect of match policy on the retirement security of plan participants, either because firms want to minimize the chance of being considered in violation of their fiduciary responsibility under the Employee Retirement Income Security Act (ERISA) or because employees at these firms more fully value company stock because of the lower firm-specific risk. Our results also suggest that some firms may match in company stock to put stock in "friendly hands" to help thwart takeovers. Firms with multiple classes of stock, which confer superior voting rights on management, are less likely to match with company stock, consistent with Rauh (2003) who found that state takeover laws and the company stock holdings in defined contribution (DC) plans of companies incorporated in those states are substitutes. In addition, we find that the likelihood of an employer match in company stock increases with the dividend yield, likely because of the tax benefit associated with dividends paid on stock in leveraged ESOP plans. ${ }^{4}$ However, the relation with dividends is not robust.

We then confirm the findings of prior work concerning the effect of the 401(k) match on participant behavior. Consistent with past research (Benartzi, 2001; Liang and Weisbenner,

\footnotetext{
${ }^{3}$ An 11-k statement is an annual report of a firm's defined contribution plan that details changes in plan assets over the past year such as employee and employer contributions to the various investment options. See Section II for a further description.

${ }^{4}$ The firm is allowed to deduct dividends paid on stock contributed to leveraged ESOP plans from taxable income. The match component of a defined contribution plan can be converted to a leveraged ESOP to reap this tax deduction for dividends.
} 
2002), we show that having an employer match in company stock leads employees to increase their own purchases of company stock, resulting in even more concentrated holdings. This finding has been attributed to a match in company stock being interpreted by employees as implicit investment advice that company stock is a good investment. Further, we document that about two-fifths of this boost in company stock purchases comes from a reduction in contributions to the safest, lowest-return asset in the plan, typically a money market fund.

Using our data on firm characteristics and the effect of employer match on employee behavior, we then present simulations of the expected distribution of $401(\mathrm{k})$ account balances at retirement in order to assess the effect of an employer match in company stock on participant retirement security. We present a number of alternative simulations to capture both the direct effect of the match (i.e., the entire match is made in company stock) and the indirect effects of the match (e.g., individuals contribute more of their own contribution to company stock when the match is in company stock). Rather than imposing a strictly optimal portfolio selection, we parameterize the simulations to reflect the available evidence on how $401(\mathrm{k})$ plan participants actually behave. In particular, we assume an "average" participant follows a naïve $1 / n$ diversification heuristic when choosing own contribution allocations (Benartzi and Thaler, 2001; Liang and Weisbenner, 2002), boosts own allocations to company stock in response to a match in company stock (Benartzi, 2001; Liang and Weisbenner, 2002), and rarely rebalances assets (Samuelson and Zeckhauser, 1988; Ameriks and Zeldes, 2001), which leads to a greater share of assets in equities in company stock match portfolios. These parameterizations result in an asset composition of the simulated contributions and account balances that correspond well to observed 401(k) plans. In later simulations, we consider the desirability of a match in company stock for participants that would otherwise invest all of their own contributions in only one asset.

The simulations demonstrate the dual effect of matching in company stock, namely an increase in the mean account balance and an increase in the variance of its distribution. Perhaps surprisingly, the simulated account balances for participants at retirement age indicate that given the historical equity premium, sufficiently risk-tolerant participants would prefer a plan that offers a company stock match to a plan that offers an unrestricted match. This preference increases with the amount of other uncorrelated wealth (e.g., Social Security, home equity, etc.).

The preference for a plan at a firm with a company stock match rather than at a firm with a choice match primarily reflects two factors. First, firms that match with company stock have 
lower stock price volatility and lower bankruptcy risk than firms with a choice match. Second, given participant behavior, the effect of a match in company stock is to increase the share of assets held in equities and reduce the share in lower-yielding and lower-risk fixed-income securities (e.g., money market funds and long-term bonds). Naturally, the assumed equity premium plays a key role in assessing the preference for a match in company stock. Imposing a four-percentage point reduction in the equity premium, i.e., cutting the historical premium in half, significantly reduces the risk aversion level at which participants would prefer the distribution of outcomes under a company stock match to an unrestricted match.

A company stock match is also generally preferred to an unrestricted match if participants do not diversify their own contributions (i.e., do not adopt the $1 / \mathrm{n}$ strategy). For example, when the match is in company stock, participants who would otherwise concentrate their own and their employer's contributions in a fixed-income security (e.g., stick with the default investment option which is typically a money market fund) obtain equity exposure and gain from diversification that they would otherwise not receive. On the other hand, if participants would otherwise concentrate their investments in a small-cap equity fund, then the company stock match has little to offer in terms of higher expected returns from additional exposure to equities but exposes the individual to more idiosyncratic risk. In this case, the distribution of account balances is less favorable to the company stock match.

These simulations provide several interesting insights into the effect of a company stock match on retirement wealth. Although we find that one reason for the desirability of a company stock match is the greater holdings of equities that results, this finding is not meant to suggest that matching with company stock is the best way to increase 401(k) participants' exposure to equities. That is, the company stock match does not yield a mean-variance efficient portfolio. Rather, it improves a participant's distribution of retirement wealth if his portfolio otherwise would have had too little invested in stock, either because he followed a $1 / \mathrm{n}$ investment rule or because he concentrated his investments in a single fixed-income security. Neither do our results indicate that workers would want firms that currently provide an unrestricted match to switch to requiring that employer contributions be in company stock. Indeed, the significantly higher risk of firms that offer an unrestricted match would substantially increase the variance of account balances if these firms were to switch match policy, and only the most risk-tolerant employees would be better off from such a change. Overall, the results of our simulations suggest that the 
preference for a plan at a company that matches with company stock depends importantly on the lower risk of firms that provide such a match. Further, since firms do not have incentives to guide participants to equities other than company stock, the equity exposure obtained through a company stock match, while inefficient, may be better than the alternative asset composition under a choice match, particularly if participants stick with low-yielding default investment options (Choi, Laibson, Madrian, and Metrick, 2001).

The paper proceeds as follows. In Section II, we provide further details on the data. Section III presents our empirical analysis of employer match policy. Section IV traces the effect of employer match policy on employee behavior. We provide simulation results in Section V. Section VI concludes and discusses policy implications.

\section{Data and Sample Characteristics}

Our primary data source is the 11-k form filed with the SEC by 401(k) plans for which the option to invest in company stock is deemed an offering of securities. From these filings we collect total participant contributions, participant contributions to company stock, participant contributions to money market funds or GICs, the employer's match policy (i.e., are employer contributions restricted to company stock), total employer contributions, employer contributions in company stock, total plan assets, total company stock holdings, and the number of investment alternatives. For the few firms with multiple plans, we collect data for the largest plan.

Starting with all U.S. firms listed in Compustat any year from 1993 to 1999, we identify firms that filed an 11-k at least once during 1994 to $2001 .^{5}$ We were able to hand-collect data for 946 companies that offered a match to employee contributions, yielding 3,179 firm-year observations. As reported in table 1, most of the data are in the period 1993 to 1998, with the largest number of firms, 635, in 1998. On average, there are 3.4 observations per firm, with 42 percent of the firms with 2 observations or less and 58 percent of the firms with 3 or more observations. The information provided on the $11-\mathrm{k}$ is in accordance with ERISA reporting guidelines. In 1999, there was a change in ERISA reporting requirements that led to fewer companies reporting contributions by asset category, leaving us with contribution data for far fewer plans in 1999 and 2000 than in 1998.

\footnotetext{
${ }^{5}$ 11-k filings are available on the SEC's Edgar website starting in 1994. The 1994 filing reports plan activity during 1993. Some firms will report not only plan activity during the past year, but plan activity over the past three years. Thus, we have 174 observations in 1992 and 49 observations in 1991.
} 
Information on stock prices and return variance are from the Center for Research in Security Prices (CRSP) database. Other firm financial data, including market-to-book ratios, assets, employees, debt ratings, dividends, and cash flow (operating income before depreciation) are from Compustat. Details on defined benefit plans are from Department of Labor (DOL) 5500 data and Compustat.

To characterize our sample, we focus on firms in the sample in 1998, one of the more recent years with the largest number of firms. As shown in table $2 \mathrm{a}$, about one-half of the sample was a member of the S\&P 1500 during $1998 .^{6}$ Thus, the typical firm in our sample is smaller, measured by both market value and employees, than the typical S\&P 1500 firm, but is larger than the average of all public companies, as available from Compustat. The sample represents a broad cross-section of industries. As noted in the table, 15 percent of the sample is in the technology sector, somewhat less than the overall market.

Companies that issue shares for their retirement plan, rather than purchase shares on the open market, are required to file an 11-k. This raises the possibility that the sample could be biased toward firms that do not repurchase stock. While data on plans that exclusively buy shares on the open market for the plan are not publicly available, we are able to document that repurchase activity by firms in our sample does not differ from that at other publicly-traded firms. ${ }^{7}$ Specifically, we find that roughly half of the firms in the sample repurchased stock in 1998 (just evidently not in conjunction with their retirement plan), and as shown in the bottom row of table $2 \mathrm{a}$, the share repurchase yield (an estimate of the fraction of shares repurchased) for the sample was 1.8 percent in 1998, similar to the yield for the S\&P 1500 and all firms.

We also compare our sample of plans to those at publicly-traded firms as reported on Form 5500 filed with the DOL. ${ }^{8}$ In the aggregate, for our sample of the largest plans at 635 companies in 1998, total plan assets were \$264 billion, representing 38 percent of the \$698 billion in plan assets at all publicly-traded companies (table 2b). Total contributions by participant and company for our sample totaled $\$ 15.2$ billion, just over 30 percent of the $\$ 49.2$ billion for publicly traded firms. Estimates from the DOL for 1998 for all US companies, public

\footnotetext{
${ }^{6}$ The S\&P 1500 consists of the 1500 stocks that comprise the S\&P 500 index, the S\&P 400 MidCap index, and the S\&P 600 SmallCap index.

${ }^{7}$ In the uncommon event that the plan does not allow employees to purchase stock but does provide the employer match in company stock, it would generally not be deemed an offer of securities, and the plan would not be required to file. In our discussion with SEC staff, the onus is on the company to determine whether it needs to file an 11-k. ${ }^{8}$ Publicly-traded companies in the DOL Form 5500 data set were identified by whether they had a CUSIP, and by matching EINs with those in Compustat.
} 
and private, are $\$ 1.54$ trillion in assets and $\$ 135$ billion in contributions.

For our sample of 635 companies in 1998, company stock totaled $\$ 97$ billion, representing 37 percent of plan assets. One-third of total participant and employer contributions were allocated to company stock (employees in aggregate contributed one-quarter of participant contributions to company stock). The DOL 5500 data indicate that at public companies, the share of defined contribution plan assets held in company stock was 39 percent, similar to the share for our sample. Thus, our sample represents two-fifths of 401(k)-type plan assets at all publicly traded companies in 1998, and the fraction of assets invested in company stock is similar to that of all publicly traded companies.

\section{Empirical Analysis of Employer Match Policy}

\section{A. Summary Statistics Regarding the Employer Match in Company Stock}

As noted in the first row of table 3, 39.3 percent of the 3,179 firm-year observations required that the entire employer match be in company stock, comparable to the one-third reported by the Profit Sharing / 401(k) Council of America (2002). ${ }^{9}$ Such a requirement has substantial consequences because, for a typical employee who contributes six percent of salary and receives a match of $\$ 0.50$ per dollar up to this limit, the match would account for one-third of the total (employee plus employer) contributions. However, match policy has an even larger effect because employees respond to a match in company stock by boosting their own voluntary purchases, perhaps because they interpret the employer match as implicit investment advice that company stock is a good investment. Rows 2 through 8 of table 3 assess the effect of match policy upon the concentration of company stock holdings in 401(k) plans.

In row 2 of table 3 , we show that, in our sample, participants at firms with the employer match in company stock allocated 9.5 percentage points more of their own contributions to company stock. Thus, after factoring in the match, participants at firms with a company stock match had on average 45.5 percent of their total annual contributions being invested in company stock, compared to 17 percent at firms with an unrestricted match (row 3). This large share of contributions allocated to company stock is not simply because of the match requirement, as required purchases of company stock at these companies are on average 28 percent of total

\footnotetext{
${ }^{9}$ Firms rarely change their match policy, as only 41 of 946 firms switched from an all company stock match to an unrestricted match or vice versa during the sample period.
} 
annual contributions, or only three-fifths of the observed company stock purchases. ${ }^{10}$ The annual contributions appear to translate into similarly-concentrated asset holdings: as shown in row 5, the percent of plan assets held in company stock averaged 42 percent at firms that matched in company stock, versus 18 percent at firms with an unrestricted match.

In addition, the size of the employer match relative to employee contributions does not differ substantially across firms by match policy. In row 6 of table 3, we see that the ratio of employer to employee contributions averages 46 percent at firms that match in company stock, and 53 percent at firms with an unrestricted match, but the difference is not significant. Median ratios show a similar pattern, 37 and 40 percent respectively, with the difference significant but not large.

Rows 7 and 8 show that, as expected, firms that match in company stock have a significantly higher fraction of their total outstanding shares held inside the 401(k) plan. The amount of company stock held inside the 401(k) plan at company stock match firms averaged 4.5 percent, exceeding that for choice match firms by 2.9 percentage points. The annual purchase of company stock via employee and employer contributions represented nearly 0.6 percent of the shares of company stock match firms. Within 401(k) plans of firms that match in company stock, the number of shares held in the plans is comparable to the number of outstanding employee stock options held by non-executives, as reported in Core and Guay (2001) and Liang and Weisbenner (2001). This suggests that when studying stock-based compensation to lowerlevel employees, incorporating stock received through the pension plan could be important.

The difference in the amount of stock held in 401(k) plans across match policy is of sufficient magnitude to help deter hostile takeover attempts. Shivdasani (1993) finds that the probability of a hostile takeover is significantly lower when a greater share of stock is held by affiliated stockholders (i.e., family trusts, company retirement plans, etc.); differences in ownership of affiliated holders amounted to four percentage points, 3.2 percent at firms that received a hostile takeover bid compared to 7.3 percent at firms that were not subject to a bid.

In row 9 we see that firms that offer a company stock match also tend to offer, on average, one fewer investment option to their plan participants. To the extent that participants

\footnotetext{
${ }^{10}$ The percent of total contributions required to be in company stock is non-zero for some firms that offer an employer 401(k) match with choice because in addition to the unrestricted 401(k) plan, these firms may also have a small profit sharing plan that when triggered (e.g., company profit targets are met) provides the employee with company stock. Less than 10 percent of choice match firms offer such an additional plan.
} 
follow naïve diversification rules (i.e., follow " $1 / \mathrm{n}$ " behavior), this would lead to a greater investment of employee contributions in company stock.

In rows 10 though 15, we provide data on the number of participants in the plans, as well as the size of account balances and the amount of contributions per participant. Data on the number of plan participants was collected by matching the 11-k sample with the DOL 5500 forms. We were able to obtain participant data for 906 of the 1232 plans for 1997 and 1998. The plans that match in company stock are typically larger than those that offer an unrestricted match, as measured by the number of participants (row 10), with the fraction of total firm-wide employees covered by the $401(\mathrm{k})$ plan averaging about two-thirds for both types of firms (row 11). Total employee contributions per participant are roughly $\$ 300$ per year higher at firms that match in company stock relative to those that do not (average employee contributions of $\$ 3100$ and $\$ 2800$, respectively, row 12 ), while the employer contributions are roughly the same (row 13). Average account balances per participant at company stock match firms are significantly greater than balances at choice match firms ( $\$ 60,600$ and $\$ 43,220$, respectively, row 14$)$, and company stock holdings are higher by nearly $\$ 20,000$ at company stock match firms (row 15).

\section{B. The Costs and Benefits of Offering a Match in Company Stock}

The decision by a firm to provide a match in company stock involves a tradeoff between a number of costs and benefits. There are two related reasons that providing a match in company stock may be costly for a firm. First, elementary portfolio theory makes it clear that an optimizing agent should prefer a diversified portfolio to one that is highly concentrated in a single asset. Rational employees would recognize that a match in company stock substantially increases the concentration of assets and therefore the volatility of their future retirement wealth and, as a result, would value a match in company stock less than a match in cash, which allows them to diversify their portfolio. ${ }^{11}$ If the company stock match is not fully valued, companies might need to provide a larger match than if it were made in cash or increase other compensation. Second, firms might be concerned that in the case of poor stock price performance, the plan sponsor could be considered by the courts to be in violation of their

\footnotetext{
${ }^{11}$ It is worth noting that there are some tax advantages to employees for holding company stock versus other stock in 401(k) plans (Iwry, 2003). Company stock withdrawn from a 401(k) plan is not taxed until the stock is sold, and then at long-term capital gains rates. In contrast, other stock holdings are taxed at typically higher ordinary income tax rates at withdrawal.
} 
fiduciary responsibilities if they had provided a match in company stock. ${ }^{12}$

To the extent that these potential costs are important to the firm, one might expect that less risky firms (i.e., lower stock price volatility and/or a lower bankruptcy rate) would be more likely to match with company stock because the additional risk imposed on workers is lower. In addition, a firm might not be as concerned about these costs if it also provides other retirement benefits, such as a defined benefit (DB) plan, which reduces the importance of 401(k) plan assets for financial security. In particular, the presence of a DB plan means that the 401(k) plan participants also have an additional asset that is largely uncorrelated with company stock performance, because DB plans are prohibited by ERISA to have more than ten percent of plan assets invested in company stock. In addition, DB plans, unlike 401(k) plans, are insured by the Pension Benefit Guaranty Corporation (PBGC). While the benefits from DB plans are at some risk if the company fails because of the fact that DB benefits are back-loaded and the PBGC is responsible for obligations incurred only up to the time at which the firm fails, the provision of these benefits mitigates the risk to retirement wealth from a high concentration in company stock. $^{13}$ Thus, firms that provide DB plans, as well as firms that have less risky stock, may feel less constrained in providing the employer match in company stock.

Firms must trade off these costs with several potential benefits to the firm from providing the employer match to 401(k) plans in company stock. A direct benefit that all firms would achieve is a cost reduction, because administrative fees for company stock are negligible and considerably less than fees associated with providing other investment options, such as equity and bond mutual funds. There are also other potential benefits to matching in company stock that likely vary across firms, which we now discuss.

First, it may be cheaper for a firm to issue stock to fund its $401(\mathrm{k})$ match than to raise funds from outside investors to provide an unrestricted match, perhaps because of asymmetric information (Myers and Majluf, 1984). This argument would predict that firms with less excess cash flow and greater asymmetric information would be more likely to offer a match in company stock, consistent with the use of stock options (Core and Guay, 2001). Low cash flow firms may also be more likely to match in company stock because of less ability to raise funds via debt.

\footnotetext{
12 Section 404(c) of ERISA generally relieves employers from liability for fiduciary error when the employer permits participants to exercise control over their retirement plan accounts. If a firm requires the match to be in company stock, however, the safe harbor provisions may no longer apply (Purcell, 2002).

13 There is also a statutory limit on the amount of benefits that the PBGC can guarantee. For plans with a 2004 termination date, the maximum guarantee is just under $\$ 45,000$ annually for a single life annuity at age 65 .
} 
Second, for firms that pay dividends, there is a tax advantage to firms that match in company stock. Any contribution to a 401(k) plan, whether paid in cash or in company stock, is initially deductible from corporate income taxes. However, by making the contribution in the form of company stock, a dividend paying firm may be able to "double dip" by receiving a future tax deduction for all dividends paid on shares held within the plan in addition to the initial deduction for the value of the shares themselves. Specifically, while dividends paid on stock are not usually tax deductible, if firms contribute the employer match in company stock to a leveraged employee stock ownership plan (ESOP), dividends paid on that stock to repay debt may be tax-deductible (Beatty, 1995; Schultz and Francis, 2002; Iwry, 2003) ${ }^{14}$ Recent business press cites that such tax savings may be significant for some firms (Schultz and Francis, 2002). We test for the importance of this tax advantage by looking at whether a firm's dividend policy helps to explain the likelihood of a company stock match.

Third, a company stock match likely leads to a greater share of the firm being held by employees. Recall that the average percent of total company stock held in the 401(k) plan was three times higher for firms that match in company stock relative to those that do not (4.5 percent and 1.6 percent, respectively). There are several potential advantages of this, including having stock in "friendly hands" to help protect the firm from hostile takeovers (Rauh, 2003). We test for this motive by examining whether firms that have multiple classes of stock, and thus already have a mechanism to thwart takeovers or protect managerial wealth in a takeover (DeAngelo and DeAngelo, 1985), are less likely to have a company stock match. Firms may also encourage or mandate holdings of company stock because of the perceived benefits from aligning workers and stakeholders' interests (Jensen and Meckling, 1976; Demsetz and Lehn, 1985; Smith and Watts, 1992). Firms with greater monitoring difficulties, as measured by number of employees (Lazear, 1979 and 1983), or greater noise in the operating environment, as measured by idiosyncratic risk (Demsetz and Lehn, 1985), might benefit more from aligning incentives. In addition, firms with a larger value in growth opportunities and intangible assets may benefit more from employee stock ownership due to the asymmetric information between insiders (i.e., employees) and outside shareholders (Holmstrom and Milgrom, 1987). As applied to our question, their model would predict that firms with higher market-to-book ratios would be more likely to offer a match

\footnotetext{
${ }^{14}$ While this benefit is not likely to encourage dividend payments, since most stock is held outside of ESOP plans and so is subject to double taxation, the benefit could encourage companies that already pay dividends to provide a 401(k) employer match in company stock in order to qualify for this deduction.
} 
in company stock (Smith and Watts, 1992).

\section{Which Factors Matter? An Empirical Analysis of Match Policy}

We are interested in determining empirically which of these potential costs and benefits are most relevant to the firm's decision about whether to offer their match in company stock versus cash. In addition to the general academic interest of this question, knowing the relative importance of these factors is crucial for guiding public policy in this area.

As shown in appendix table 1, firms that match in company stock generally have less volatile stock prices and idiosyncratic risk and are considerably more likely to also sponsor a defined benefit plan, have an investment-grade debt rating, pay dividends, and have multiple classes of stock. To assess the quantitative importance of these factors and other firm characteristics in explaining firm match policy, and thus disentangle the alternative hypotheses, table 4 presents coefficient estimates from a regression of match policy upon these firm attributes one at a time (columns 1 to 10$).{ }^{15}$ Because many of these firm characteristics are correlated (appendix table 2), we then turn to a multivariate analysis (column 11 of table 4).

As shown in column 1, whether the firm already provides retirement benefits through a defined benefit plan appears to be very important. ${ }^{16}$ The estimated effect is positive and large, suggesting that firms that have a defined benefit plan are substantially more likely, by 22 percentage points, to require the match to be in company stock. To put the size of this effect in perspective, recall that in the sample, 39 percent of firms require the match to be in company stock. Our interpretation of this result is that the provision of retirement benefits through a DB plan significantly mitigates the risk to employee retirement wealth of having $401(\mathrm{k})$ plan assets concentrated in company stock. In addition, columns 2 and 3 show a significant negative relationship between stock price volatility and the probability of matching in company stock, also suggesting that employers consider the effect of match policy on employee retirement wealth. Similarly, firms with an investment-grade bond rating, as gauged by Standard and Poor's, are 18 percentage points more likely to require the match in company stock (column 4).

We find no direct evidence that cash constraints are an important factor in setting employer match policy (column 5), as there is no direct correlation between cash flow (i.e.,

\footnotetext{
${ }^{15}$ We estimate a linear regression to provide an easy-to-interpret estimate of the marginal effects of firm characteristics on the choice of match policy. A Probit model yields very similar results.

${ }^{16}$ One could envision a scenario in which firms face the choice of offering a 401(k) plan with a match in employer stock or a defined benefit plan as alternative means to tie the worker to the firm. In our sample, however, DB plans have been in place for some time and so we are not concerned with potential endogeneity of the DB variable.
} 
operating income before depreciation) and match policy. To explore this relationship further, we split the sample into firms by whether cash flow is positive or negative, allowing the coefficient on cash flow to vary across these two types of firms. ${ }^{17}$ For the small segment of the sample (3.5 percent) that has negative cash flow, we find that the probability of a match in company stock increases as cash flow decreases (i.e., the coefficient is negative), suggesting some role for cash constraints for a select minority of firms. However, because only a small portion of the sample has negative cash flow, these results should be interpreted cautiously. Moreover, if cash flow is positive, the coefficient estimate is positive, indicating that higher cash flow increases the likelihood of a company stock match. The point estimates for these cash flow variables do not change much when other firm attributes are added, with the coefficient for positive cash flow firms remaining significantly positive. Ceteris paribus, more profitable firms matching with company stock runs counter to what we would expect if companies matched with stock because they were cash constrained and so had no other means to make a match. ${ }^{18}$

The tax-based motivation to match in company stock if dividends are paid appears to be somewhat important. Coefficient estimates suggest that a one percentage point increase in the dividend yield is associated with a 3.3 percentage point increase in the probability that a firm's match is all company stock (the sample average is 39 percent). This variable, however, is highly correlated with measures of firm risk and the presence of a DB plan, and thus the estimate becomes less precisely measured and actually flips sign once these other variables are included.

The evidence is mixed concerning motivations to boost employee ownership. The market-to-book ratio, a proxy for the presence of growth opportunities and intangible assets, is not significant, while the coefficient on $\log$ (employees) is only marginally significant on its own, with the coefficient flipping signs in the multivariate specification. Thus, the desire to align incentives and/or better monitor employees, as proxied for by these two variables, does not appear to be important factors in explaining match policy.

Finally, the effect of multiple classes of stock is compelling, decreasing the probability of a match by 17 percentage points. This result is consistent with the presence of multiple classes

\footnotetext{
${ }^{17}$ We also examined excess cash flow (cash flow less capital expenditures) and found qualitatively similar results.

${ }^{18}$ This is not to say that cash flow is not an important determinant of whether a firm offers a 401(k) plan or a match at all, but only that it is not an important determinant of the type of match that is provided. Surveys suggest that cash flow constraints are an important determinant of providing 401(k) benefits to employees (see Department of Labor, 2001), and studies have identified cash flow constraints as an important factor for terminating defined benefit pension plans (see e.g., Petersen, 1992).
} 
of shares and boosting stock in "friendly hands" (i.e., through a company stock match) as being substitutes in preventing unwanted takeover attempts. While the estimated effect of multiple classes of stock is little changed, the coefficient loses significance in the multivariate regression $(p$-value $=0.17)$.

Because these variables are highly correlated, as discussed earlier, some of these variables lose significance when all firm characteristics are included simultaneously (column 11). This specification also includes dummy variables for whether the firm went public in the 1970s, 1980s, or 1990s (going public prior to the 1970s is the omitted category), and dummy variables for the firm's two-digit SIC industry classification (the sample spans 66 distinct twodigit industries). The firm age variables are meant to control for differences in pension plan policy that may depend upon a firm's age or legacy effects (e.g., DB plans were far more common 20 years ago, the accounting and tax treatment of ESOP plans has changed over time), while the industry variables loosely control for differences in worker characteristics across industries that may influence pension plan design. Only the presence of a DB plan, an investment-grade rating, and to a lesser extent cash flow (but only for firms with positive cash flow) remain significant once all the variables are included jointly (column 11). As suggested by comparing the $\mathrm{R}^{2}$ from the individual regressions to the multivariate regression, the $\mathrm{DB}$ and investment grade variables explain the bulk of the explained variation in match policy. The increased likelihood of a match in company stock if the firm also has a DB plan is strikingly robust (point estimate is 22.3 with no other firm attributes in the regression and 21.3 in the full specification). ${ }^{19}$ On balance, the coefficients suggest that firms may be concerned about the risk of company stock in retirement portfolios and provide the match in company stock only when employees have a fall-back retirement plan or when the firm is less likely to experience financial distress. It is also consistent with the idea that these firms may view themselves as having a lower risk of being considered a poor fiduciary, and thus be more willing to restrict the employer match to company stock.

In summary, our evidence suggests that companies are primarily trading off a greater

\footnotetext{
${ }^{19}$ While the inclusion of the firm age and industry indicator variables does not affect the magnitude of the correlation between the presence of a DB plan and match policy, this is not to say that these variables do not have their own independent effects upon match policy. Both the firm age variables and the industry indicator variables are significant, with p-values of 0.09 and 0.00, respectively. For example, A firm that went public in the 1990s is 18.8 percentage point less likely to match with company stock than is a firm that went public in the 1970s or earlier, and firms in the telecommunications, utilities, and retail trade industries are more apt to match with company stock.
} 
share of stock in friendly hands and perhaps the benefits of the dividend tax advantage with the recognition that a lack of diversification may be costly to employees. Firms for which the diversification costs to employees are low (i.e., those companies with low bankruptcy risk) and firms that offer a DB plan are more likely to provide a company stock match. The implications of the lower risk and other sources of retirement income for employee welfare are examined in simulations of retirement wealth by match policy presented later in Section V.

\section{Further Analysis of Effect of Defined Benefit Plans}

Table 5 further explores one of our most robust findings, the role of the DB plan. The left panel of table 5 documents that firms are more apt to match in company stock within their $401(\mathrm{k})$ plan if they also offer a DB plan (column 1, which replicates column 1 of table 4), but even more so if the match they are offering is less generous as measured by the ratio of employer to employee contributions (columns 2 and 3). For example, among firms that offer a DB plan, as the size of the match relative to employee contributions falls from 50 percent to 20 percent of employee contributions, and thus the share of match contributions in retirement wealth declines, the probability that the firm matches with company stock rises by about six percentage points. ${ }^{20}$ In contrast, the generosity of the match has no predictive power for match policy for firms that do not offer a DB plan. Thus, firms are more apt to match in company stock if they both offer a defined benefit pension and provide a less generous match, perhaps because firms take into account the effect of match policy on the retirement security of plan participants, either due to a lower risk of the plan sponsor being considered in violation if its fiduciary responsibility or due to simple market forces (i.e., employees at riskier firms without DB plans are less likely to fully value a match in company stock).

One concern about the interpretation of the DB coefficient is whether the same employees are covered by both the DB and the 401(k) plan, or if DB benefits apply only to an earlier cohort of workers, while more recent hires are limited to participation in the 401(k) plan. Fortunately, in our sample of firms, DB benefits appear to apply largely to the same set of employees as those that contribute to $401(\mathrm{k})$ plans. While there are no data available from the 11-k, 5500 form, or Compustat to establish the fraction of employees that are covered by both types of plans, other data strongly suggest that it is the case. In the aggregate, data from the 1998 Survey of Consumer Finances indicate that of the roughly 40 million households with a member

\footnotetext{
${ }^{20}$ In the sample, the interquartile range for the ratio of employer to employee contributions is 0.28 to 0.58 .
} 
that works at a firm with more than 500 employees and that is covered by a defined benefit plan, 62 percent of these workers also participate in a defined contribution (DC) plan. Data from the DOL 5500 data present roughly the same picture - 69 percent of wage and salary workers that were covered by a DB plan also were covered by a DC plan in $1998 .^{21}$

In the right panel of table 5 we focus attention on the subsample of firms over 1997 and 1998 that offer broad-based plans where it is likely that workers are covered both by a DC and DB plan, if the firm offers both. To construct this sample, we first obtain the number of plan participants from the DOL 5500 form and then compare this number with the number of total employees from Compustat. If the number of participants in the DC plan and, in the cases when it is offered as well, DB plan total at least 50 percent of total firm employees, then we define the plan to be broad-based, and include the firm in the regression. ${ }^{22}$ Relative to the results for the full sample (table 5, left panel), the estimated effect of the presence of a defined benefit plan remains highly significant, with the point estimates little changed. The results obtained with this subsample of firms with broad-based plans support the conclusion that firms are more likely to match in company stock when workers have alternative wealth in DB benefits.

\section{E. Survey Evidence on Costs and Benefits of Match Policy}

The Vanguard Group (2003) conducted a survey of 76 firms to ascertain employer attitudes toward company stock in $401(\mathrm{k})$ plans. The firms were asked whether they agreed or disagreed with various statements concerning potential costs and benefits of matching with company stock in 401(k) plans. Table 6 presents the results of the survey, with responses broken down by whether the firm actually matches with company stock or allows choice. The results of the survey are quite striking and are very consistent with our empirical findings. Employers seem to divide into two camps in terms of their beliefs regarding the costs and benefits of a match in company stock. Those that match in company stock feel less concern for the reduction in diversification for participant accounts and feel there is less risk that a match in company stock will be deemed a breach of fiduciary responsibility and result in a lawsuit. These survey responses are in keeping with the empirical findings that firms that match with company stock are more apt to provide other sources of retirement income (i.e., a DB plan) and have lower stock price volatility and bankruptcy risk.

${ }^{21}$ Calculations from Table E4b, Private Pension Plan Bulletin, US DOL, Winter 2001-2002.

${ }^{22}$ The 50 percent threshold is selected to assure there will be an overlap between workers covered by the DC plan and those covered by the DB plan. Regressions estimated with higher thresholds yield similar results. 
On the benefits side, those that match with company stock are significantly more apt to view having stock in friendly hands and promoting employee stock ownership as important reasons for a company stock match. The first survey response is consistent with our empirical result that the presence of multiple classes of shares and boosting stock in "friendly hands" (i.e., through a company stock match) are substitutes. However, we do not find empirical support for the notion that employers match in company stock because the company realizes benefits from greater employee stock ownership. Indeed, the Vanguard Group survey finds no difference in self-reported motivational levels between surveyed employees that hold company stock in their 401(k) plan and those that do not.

\section{Effects of Match Policy on Employee Purchases}

Given that on average the employer match represents about a third of total contributions, a match in company stock forces employees to hold a substantial share of their retirement portfolio in company stock. Further, as previously documented in table 3, a company stock match leads employees to boost their own voluntary purchases of company stock. Previous research (Benartzi, 2001; Liang and Weisbenner, 2002) have described this result as consistent with employees viewing a match in company stock as the firm's implicit endorsement of company stock as a good investment.

We next estimate the effect of plan characteristics (i.e., match policy and the number of options), past asset returns, and firm characteristics on the percent of employee contributions invested in company stock, the firm's lowest-return asset (a money market fund, or if not offered, a Guaranteed Investment Contract (GIC)), and all other investment options. The results are displayed in table 7. When the employer match is in company stock, the percent of employees' own contributions allocated to company stock are seven to eight percentage points higher. This boost in employee contributions to company stock comes disproportionately at the expense of the safest asset; employees allocate three percentage points less to the money market/GIC fund if the employer matches in company stock. Thus, about two-fifths of the boost in company stock purchases comes from a reduction in contributions to the lowest-return asset.

Consistent with Benartzi and Thaler (2001) and Liang and Weisbenner (2002), the regressions indicate that $1 / \mathrm{n}$ is also a significant predictor of purchases across all asset classes, where $\mathrm{n}$ is the number of investment alternatives. Company stock purchases are also greater if 
stock price volatility is lower and the firm is larger, with the contributions to the money market/GIC fund increasing with stock price volatility.

The relation between asset returns and contribution decisions is in general fairly weak, with the minor exception of the effect of past Treasury bill returns. For example, relative to a firm with a zero stock return, a doubling of stock price over the past five years is associated with only a 0.5 percentage point increase in the fraction of employee contributions allocated to company stock. Past five-year Treasury bill returns are strongly positively correlated with the percent of employee contributions allocated to the money market/GIC fund, while negatively related to contributions to company stock and all other investment options.

\section{Does it Matter? The Effect of Match Policy on Retirement Wealth}

Participants in plans that match with company stock end up with a highly undiversified portfolio. However, our empirical results also indicate that these employees are more likely to work for firms that have lower idiosyncratic risk, lower bankruptcy risk, and provide other retirement income through defined benefit plans. While a higher concentration of assets in company stock entails more risk, company stock has a higher expected return than most other investment alternatives, especially money market and government bond funds. As mentioned earlier, past research finds that when making investments, employees invest consistent with naïve $1 / \mathrm{n}$ diversification strategies, rarely rebalance plan assets, and tend to place more of their own contributions in company stock if the match is provided in company stock. As a result of these many countervailing forces, the net effect of company match policy on the distribution of possible retirement wealth levels is complex. In this section, we use simulation methods to compare the distribution of retirement wealth under alternative assumptions.

\section{A. Key Assumptions and Procedures}

We assume that an individual begins contributing to a $401(\mathrm{k})$ plan at age 27 and contributes six percent of wages annually until age 62. The company matches this contribution at a rate of 50 cents on the dollar, meaning that the company contributes an additional three percent of wages each year. The individual's lifetime wage path is taken from Munnell and Sunden (2003). ${ }^{23}$ In particular, wage growth is a composite of two factors. The first is that the

\footnotetext{
${ }^{23}$ For more details on the calculation of the wage profiles, we refer readers to page 30 of Munnell \& Sunden (2003). We are grateful to these authors for providing us with the wage profiles for use in our simulations.
} 
growth in real wages across the economy is assumed to be 1.1 percent annually, which is consistent with projections of the Office of the Actuary of the Social Security Administration. The second is an age-earnings profile based on career earnings profiles for men and women born between 1926 and 1965 . Salary at age 50 is set to $\$ 44,000$, which is the median wage for a 50 year old covered by a pension plan in the 2001 Survey of Consumer Finances.

Consistent with our 11-k data, we assume that firms offer seven investment options (the median number of options in our sample) - company stock, large-cap equities, money market, long-term government bond, a balanced fund (which is invested in a monthly rebalanced mix of 50 percent stocks and 50 percent bonds), high-grade long-term corporate bond, and small-cap equities. Based on our results from table 7 and previous research findings (Benartzi and Thaler, 2001; Liang and Weisbenner, 2002), we assume initially that participants invest their own contributions using a simple $1 / \mathrm{n}$ diversification heuristic. ${ }^{24}$ We also assume that when the company matches with cash, the individual invests the employer match in the same manner as their own contributions. In our base case simulation, we assume that the company's decision to match in company stock has no effect on an employee's own contribution allocation, although we alter this assumption in later specifications. As such, for many of the simulations presented, the difference in annual purchases of alternative assets arises solely from a difference in the employer match. These assumptions approximate the actual contribution data to money market funds and company stock that we observe for these firms. Consistent with previous research (Samuelson and Zeckhauser, 1988; Ameriks and Zeldes, 2001), we assume that participants do not rebalance their accounts. This assumption is also consistent with restrictions that many firms had in place that did not allow participants to diversify out of employer match contributions until certain age and service requirements were met.

Specifically, our assumptions of $1 / \mathrm{n}$ and seven investment options lead to one-half of annual employee and employer contributions directed toward equities and one-half toward fixed income securities at firms that match in cash. For firms that match in company stock, two-thirds are directed toward equities and one-third toward fixed income. Initially, we assume that participants do not alter their portfolio allocation when forced to receive a match in company stock, although we relax this assumption below. As discussed below, these parameterizations

\footnotetext{
${ }^{24}$ In later simulations, we further consider the desirability of a match in company stock for participants that would otherwise invest all of their own contributions in one asset.
} 
result in an asset-composition of the simulated contributions and account balances that closely correspond to observed 401(k) plans.

To estimate retirement wealth, we need to specify processes for asset returns. Monthly returns to the assets --- large-cap equity, small-cap equity, money market, long-term government bond, and high-grade long-term corporate bond --- are reported in Ibbotson Associates (2002) from January 1927 through December 2001. The historical annual returns averaged approximately 12 percent for large-cap equities, 17 percent for small cap equities, 4 percent for money market (i.e., Treasury bills), just below 6 percent for long-term government bonds, and just above 6 percent for high-grade corporate bonds.

We draw randomly with replacement from the historical distributions of monthly returns from 1927-2001, with the returns for the assets other than company stock and an inflation rate drawn as a package for a given month in order to retain all within-month, cross-asset correlations. For company stock returns, we simultaneously draw the returns of four factors (the three Fama-French (1993) factors that summarize the overall market excess return, the performance of small stocks relative to big stocks, and the performance of value stocks relative to growth stocks, and the fourth momentum factor that summarizes the performance of stocks with recent gains relative to stocks with recent losses) for the same month, and use these to generate an expected return on company stock using the individual firms' estimated betas from the four-factor model proposed by Carhart (1997). ${ }^{25}$

We estimate the betas for the four-factor model using CRSP stock returns for 1991 to 2001. For each of the 867 firms that had at least 24 months of stock returns over the period 1991-2001 and whose match policy did not change over the sample, we estimate regressions of monthly stock returns on the four factors. ${ }^{26}$ Specifically, following a standard approach in the finance literature, the excess stock return (stock return less the risk-free rate) is related to the market return (also in excess of the risk-free rate), the return of small capitalization minus big capitalization stocks (SMB), the return of high book-to-market minus low book-to-market stocks (HML), and the return of stocks that have risen the past eleven months minus those that have fallen (UMD). As shown in table 8, average raw returns and excess returns computed from the

\footnotetext{
${ }^{25}$ The four factor returns are taken from http://mba.tuck.dartmouth.edu/pages/faculty/ken.french/data_library.html. ${ }^{26}$ Of the original 946 firms in the sample, 41 had a change in match policy over the sample, 23 could not be linked with CRSP, and 15 were successfully merged with CRSP but did not have 24 months of returns, resulting in the final sample of 867 firms.
} 
four-factor model do not differ significantly across match policy. With the exception of the size factor, there is no difference in systematic risk across the two groups of firms. The SMB beta is significantly smaller for firms with a company stock match, reflecting that firms that match with company stock tend to be somewhat larger. However, total risk (the standard deviation of monthly returns) and idiosyncratic risk (the standard deviation of the residual from the fourfactor return model) are both significantly lower for firms with a company stock match, on the order of 1.5 to 2.1 percentage points per month.

After using the estimated excess return and betas and the monthly draw of the four factors from the historical return distribution to compute the expected return on company stock, we then draw randomly from the company stock return error distribution, a normal distribution with variance based on the estimated idiosyncratic risk of the firm, and apply it to the expected return to generate the realized return for that month. ${ }^{27}$ These rates of return are then applied to existing account balances and new contributions. This process is repeated for each month that the individual is contributing from age 27 through age 61 , a total of 420 months. We then save the total account balance at age 62, and repeat this process 100,000 times for each of the 867 firms in our sample. ${ }^{28}$

\section{B. Simulations of 401(k) Account Balances}

1. Base case. In the first scenario of table 9, we present results for the base case, comparing the distribution of retirement account balances when investments are made with the $1 / \mathrm{n}$ rule and the employer match is unrestricted or required to be in company stock. To construct the table, we run the simulation exercise for each of the 574 choice companies and each of the 293 firms that match in company stock based on each firm's characteristics. For each firm, we then take the simulated final account balances at age 62 and sort them into a distribution from the lowest to the highest. In order to make comparisons between the two types of plans, we then construct the median across firms of each sample statistic. Thus, the reported $1^{\text {st }}$ percentile for choice firms represents the median of the $1^{\text {st }}$ percentile of the 574 choice companies, and the reported $1^{\text {st }}$ percentile for the company stock match firms represents the median of the $1^{\text {st }}$

\footnotetext{
${ }^{27}$ The inclusion of the years 1997 to 2000 , when realized stock returns were high, does not materially affect our estimates of expected returns (i.e., excess returns and betas). Estimating excess returns and betas using stock returns over the subsample 1991 to 1996 results in total and idiosyncratic risk that are a bit lower, but the difference in risk across match policy is quite similar to that estimated using the full sample of returns.

${ }^{28}$ Through repeated experimentation, we found that 100,000 simulations is sufficient for the distribution of account balances to stabilize.
} 
percentile for these 293 companies, and similarly for the reported mean and eight other key points in the distribution. We also report the percent of times that an individual would have more wealth with company stock than with choice. This represents the point in the distribution of $401(\mathrm{k})$-plan wealth where balances are the same across match policy (i.e., the crossover point of the two distributions).

Recognizing that most investors are risk averse, and therefore have a nonlinear valuation of the possible distribution of outcomes, the bottom panel of the table reports the coefficient of relative risk aversion (CRRA) such that the individual would be indifferent between the two distributions. Specifically, we use the standard utility function of the form:

$$
U(W)=\frac{W^{(1-\gamma)}-1}{(1-\gamma)}
$$

Note that when $\gamma=0$, the individual is risk neutral, and higher values of $\gamma$ indicate higher levels of risk aversion. The case of $\gamma=1$ corresponds to $\log$ utility. We search for the value of $\gamma$ such that the expected utility from the two distributions is the same. Note that up to this point we have made no assumptions about utility maximizing behavior, but rather have focused on understanding the effect of match policy on retirement wealth, given our empirical estimates of how plan participants actually respond to match policy. Our use of a utility evaluation here is meant to provide a summary statistic for a nonlinear valuation of the distribution of outcomes that places more weight on "bad" events. We report these results conditional on having varying amounts of additional uncorrelated wealth at retirement.

The results of our base case indicate that retirement-age account balances at choice firms are larger than the account balances from company stock match firms 31 percent of the time. Conversely, balances at company stock match firms are larger 69 percent of the time, indicating that the median balance is larger. The difference in the mean account balance is substantial, with a company stock match having a mean account balance 27 percent higher than the plan with choice. An examination of the full distribution illustrates the basic result of having a match in company stock, namely that the mean is higher but there is substantially greater dispersion. At the $1^{\text {st }}$ percentile of the distribution, the company stock match results in retirement wealth that is 17 percent lower than under a choice match, whereas at the $99^{\text {th }}$ percentile, the company stock match outcome is 50 percent greater than that of the choice outcome.

For CRRA utility, what matters is the size of the gains and losses relative to total wealth. 
In addition to the wealth from the 401(k) plan, we recognize that most retirees have additional wealth in the form of Social Security, defined benefit plans, home equity, and so forth. If this other wealth is perfectly correlated with $401(\mathrm{k})$ wealth, then the results would be identical to the case in which only $401(\mathrm{k})$ wealth is considered. To the extent that some of this wealth is uncorrelated, such as Social Security wealth, it increases one's tolerance for risk within the 401(k) plan. To illustrate the quantitative importance of additional wealth outside of the 401(k) plan, we report the risk aversion coefficient assuming the individual has additional uncorrelated wealth ranging from zero to \$1 million. Using the Health and Retirement Study (HRS), Poterba, Rauh, Venti, and Wise (2003) estimate wealth holdings of households with a male at retirement age (i.e., between 63 and 67) across education groups. Annuitized wealth (i.e., the present discounted value of expected Social Security and defined benefit pension wealth) is $\$ 240,800$ for the median household with less than a high school education and $\$ 375,500$ for those with at least a college degree (the Social Security component of annuitized wealth is $\$ 217,000$ and $\$ 248,800$ for the two groups, respectively). Total household wealth excluding DC plan accounts but including expected Social Security and DB benefits ranges from $\$ 362,300$ for the median household with less than a high school education to $\$ 1,102,400$ for households with at least a college degree. This suggests that for utility comparisons, assuming $\$ 250,000$ or $\$ 500,000$ of wealth uncorrelated with the $401(\mathrm{k})$ account balance would be reasonable.

We find that individuals would prefer a company stock match to a choice match if their risk aversion level (CRRA) was 2.9 or lower, assuming they have $\$ 250,000$ of additional uncorrelated wealth. With $\$ 1$ million of uncorrelated wealth, the CRRA below which the individual prefers the company stock match is 6.1 . With no uncorrelated wealth, individuals with a risk aversion coefficient below 1.8 prefer the company stock match.

In interpreting these results, it is important to note that the level of uncorrelated wealth may differ between individuals across match policy assumptions. For example, as shown in the appendix, individuals in companies whose 401(k) plan matches in company stock are substantially more likely to also have a defined benefit plan. By comparing our match and choice assumptions at equivalent levels of uncorrelated wealth, we may in fact be biasing these calculations against the company stock match.

The outperformance of the retirement portfolio at company stock match firms reflects two factors. First, more contributions are directed toward higher-yielding assets when the match 
is provided in company stock, which implies that less is invested in lower-yielding assets. Second, company stock match firms have lower risk, which, for an equal share in company stock, reduces the likelihood that the portfolio balance at these firms will fall below the balance at unrestricted match firms.

To illustrate the effects of these two factors in explaining the desirability of a match in company stock, we present two counterfactual scenarios. The first counterfactual scenario compares the distribution of account balances when a firm that actually matches in company stock provides an unrestricted match to account balances when the firm instead follows its actual policy of matching with company stock. This scenario holds constant stock characteristics, while allowing match policy and the share of assets in company stock to vary, thus isolating the effect of differences in asset holdings on the distribution of account balances. In the second scenario, we hold match policy constant (i.e., both types of firms are required to match in company stock), thus isolating the effect of the differences in stock characteristics across choice match firms and company stock match firms on the distribution in account balances. The results of these two scenarios are shown in the second and third sets of columns in table 9. Note that in the base case, "vary match policy", and "vary firm characteristics" scenarios, the rightmost column describes the distribution of account balances when a company stock match firm matches with company stock. Thus, these three columns report identical numbers.

The "vary match policy" simulation indicates that the stock characteristics of company stock match firms (i.e., their lower idiosyncratic risk) contributes to the desirability of the company stock match found in the base case. Recall in the base case, when the comparison is a choice match firm with a choice match versus a company stock match firm with a company stock match, the company stock match outperforms the choice match 69 percent of the time, and the distribution of account balances under the company stock match plan is preferred to participants with a CRRA of 2.9 (assuming $\$ 250,000$ of uncorrelated wealth). However, when the comparison is a company stock match firm with a choice match versus a company stock match firm with a company stock match, the company stock match outperforms the choice match only 59 percent of the time, and the indifference level of risk aversion falls to 2.3. Thus, controlling for stock characteristics, a match in company stock is still desirable given sufficient risk tolerance due to the increased exposure to equities. However, the company stock match is more attractive if stock characteristics are not held constant across match policy, as firms that match 
with company stock have lower idiosyncratic risk which, ceteris paribus, tightens the distribution of retirement wealth.

In the "vary firm characteristics" simulation, we isolate the effect of differences in stock characteristics on retirement wealth by comparing the distribution of account balances when choice firms match with company stock (the counterfactual situation) to the distribution of account balances when company stock firms match with company stock. Thus, in both cases, participants are getting the same exposure to equities, but the employees of choice firms are getting exposure more inefficiently (i.e., by investments in a single stock with a similar expected return but more risk). The distribution of account balances at company stock firms is much more favorable than that at choice firms - the account balances at company stock firms outperforms those at choice firms $88 \%$ of the time, and only risk-neutral participants (i.e., CRRA less than 0.6) would prefer the retirement plan at the choice firms (assuming both choice and company stock firms match with company stock).

\section{Fees, indirect effects of match policy, bankruptcy, and lower equity premium.}

Having established that the relative performance of the portfolios depends importantly on both the share of assets in company stock as well as firm characteristics, we present scenarios in table 10 in which we alter some of our simplifying assumptions to assess whether they affect our result of a preference for a plan at a company that matches with company stock. In scenario 2, we add fund management expenses, which make company stock more attractive because it has very low or zero administrative costs, while other investment options have higher costs. We assume zero costs for company stock, and make assumptions concerning management expenses of other assets that are in line with costs at corporate plans reported in a confidential industry study. Given the assumed asset composition of total contributions (i.e., employee and employer), these assumed fees translate into a $\$ 0.31$ reduction per $\$ 100$ of contributions for company stock match firms compared to a $\$ 0.21$ reduction for choice match firms, a difference of ten basis points. ${ }^{29}$

As illustrated in scenario 2, the difference in costs compounds over time, with the lower relative fees for company stock making the company stock match more attractive. Despite a significantly lower average account balance before adding administrative costs, a participant in a

\footnotetext{
${ }^{29}$ Samwick and Skinner (2003) assume expenses of 42, 71, and 92 basis points for money market, bond, and equity funds, respectively, based on Investment Company Institute (ICI) data for funds outside of 401(k) plans. Using these higher expenses would increase the advantage of company stock relative to these alternative assets, roughly doubling the difference in total fees across match policy.
} 
plan with a choice match pays on average $\$ 23,000$ more in fees over the 35 -year period than does a participant in a plan with a match required to be in company stock; the higher fees for the choice firms thus reduce their average 401(k) account balance by roughly 2 percent. Participants with $\$ 250,000$ in uncorrelated wealth and a CRRA up to 3.5 now prefer the company stock match. The indifference level of risk aversion is 7.6 with $\$ 1$ million of outside wealth, and 2.0 with no outside wealth.

The next two scenarios incorporate the indirect effects of a company stock match policy that were discussed in Section IV, on top of the administrative costs. Scenario 3 recognizes that the employer match in company stock leads participants to increase their own voluntary purchases of company stock, and scenario 4 makes the additional assumption that firms that match in company stock typically offer one fewer alternative investment choice in their plan. ${ }^{30}$ Since we only observe how participants invest given the match policy of their firm, but not under the counterfactual, an implicit assumption underlying the utility comparisons for scenario 3 is that employees in a firm with a company stock match would invest their contributions differently if they switched to an unrestricted match firm, and vice versa. These indirect effects lead to greater purchases of company stock in company stock match firms, boosting the annual share of employee contributions invested in company stock from 14 to 24 percent, and the share of total contributions invested in company stock from 42 to 49 percent.

Not surprisingly, the incorporation of these effects jointly boosts the mean account balance at company stock match firms by $\$ 84,000$ (from $\$ 1,178,000$ in scenario 2 to $\$ 1,262,000$ in scenario 4) or seven percent. The mean balance under a company stock match is 41 percent higher than that under a choice match. However, incorporating these indirect effects increases the dispersion in account balances, slightly raising the risk that the portfolio will underperform the choice match portfolio (from 28 to 30 percent) and reducing the indifference risk aversion level from 3.5 to 3.2 (assuming $\$ 250,000$ of additional wealth).

The result of these parameter choices is a portfolio allocation for both contributions and account balances that closely match those of actual 401(k) plans. Our assumptions for

\footnotetext{
${ }^{30}$ Under scenario 3, two-fifths of the indirect boost in company stock purchases comes from a reduction in contributions to the safest asset, the money market fund, with the remaining three-fifths of the reduction evenly distributed across the remaining five options. Under scenario 4, the company stock match plan now offers six options, which boosts employee contributions to company stock by approximately 2.4 percentage points (i.e., 16.7 $14.3=2.4)$. Rather than eliminate fully one of the six non-company stock assets, we reduce employee contributions to these six assets by approximately 0.4 percentage points each, i.e., (16.7-14.3)/6.
} 
contributions lead to participants in company stock match (choice match) plans investing 24 percent (14 percent) of employee contributions in company stock, comparable to the observed 25 percent (16 percent) recorded in table 3 . Total contributions allocated to company stock are assumed to be 49 percent for company stock match firms and 14 percent for choice firms, again very similar to the observed 46 and 17 percent, respectively. The asset composition of our simulated account balances is also in line with asset holdings in other studies. For example, Benartzi and Thaler (2001) document that among plans that offer company stock, equities account for 71 percent of assets (see also Holden and VanDerhei, 2001a). In our simulations, this corresponds to the average equity allocation across all firms after about nine years of participation. $^{31}$ At this same point, plans that match in company stock have, on average, 24 percentage points more of the account balance allocated to company stock than do firms with an unrestricted match. This is very consistent with the average difference of 24 percentage points in the 11-k data.

An important omission from our simulations thus far is the possibility of the bankruptcy of the firm, and the associated wiping out of the company stock holdings in the 401(k) account. Indeed, it was the bankruptcy of firms like Enron and Worldcom that precipitated much of the public policy interest in the question of firm match policy in the first place. To address this, we introduce a bankruptcy probability by designating each firm as being included in one of three groups - those with investment-grade bonds, speculative-grade bonds, and no rated bonds - and applying the expected default probability for that group to the firm. ${ }^{32}$ The expected default probabilities used for each group represent the median rate for that group during 1997 and 1998, as estimated by KMV Corporation, a group that implements a method that measures the likelihood that the market value of a firm's assets falls short of its liabilities. The expected default probabilities for the year ahead are 0.15 percent for investment-grade firms, 1.93 percent for speculative-grade firms, and 1.61 percent for firms with no bond rating. Across the 867 firms, the average expected bankruptcy rate is 1.1 percent per year, roughly in line with realized bond default rates that averaged about 1.3 percent per year from 1981 to 2000 according to Standard \& Poor's, and the aggregate business failure rate from 1990 to 1997 reported by Dun \&

\footnotetext{
${ }^{31}$ The Vanguard Group (2003) reports an average job tenure of 9.5 years for a sample of 401(k) participants that had access to company stock in their retirement plan.

32 Bond ratings are made by Standard and Poor's and available in Compustat. A rating of BBB- or better is classified as investment grade. For firms that changed bond rating over the period, we calculated the average rating over the period.
} 
Bradstreet. ${ }^{33}$ These rates imply that a firm has a 32 percent chance of failure over the 35 -year investment horizon.

We implement this bankruptcy procedure by calculating a return cut-off that corresponds to the bottom $0.15,1.93$, or 1.61 percent of the return distribution for each group. When the random return draw for a particular company is lower than the bankruptcy return cutoff for that firm's group, we set the company stock account balance to zero. Following Poterba, Rauh, Venti and Wise (2003), we assume that the individual continues to participate in a 401(k) plan after bankruptcy, with new contributions commencing in the following month. ${ }^{34}$ Variation in bankruptcy rates across firms therefore depends both on which default group the firm is in and the firm's stock price volatility, as firms with greater volatility are more likely to hit the bankruptcy return cutoff. For our sample, the expected default probability averages 0.59 percent for company stock match firms, and 1.41 for choice match firms, substantially higher both because there are fewer investment-grade firms in the choice match group and because these firms have higher idiosyncratic risk.

Scenario 5 shows that bankruptcy risk slightly reduces the mean and median account balances, but the balances for the company stock match plan still exceed the choice match plan balance two-thirds of the time. It is still the case that sufficiently risk-tolerant individuals (CRRA of 2.7 with $\$ 250,000$ of uncorrelated wealth) would prefer the company stock match.

The limited effect of bankruptcy might at first seem somewhat puzzling, but it can be explained by two factors. First, the firms that match with company stock have a substantially lower risk of bankruptcy, as reflected in their greater likelihood of being rated investment grade and lower stock price volatility. Thus, while employees at company stock match firms have more of their account subject to bankruptcy risk (i.e., invested in company stock), bankruptcy happens less frequently. Second, bankruptcy, which reduces company stock holdings to zero, is related to the realization of a very bad outcome, which, in the absence of the forced bankruptcy, would already have reduced company stock holdings substantially. In our previous simulations, it was possible to have monthly return realizations at the bottom tail of the distribution as low as

\footnotetext{
${ }^{33}$ See Standard \& Poor's (2001) and Dun \& Bradstreet, Table B-96 in the Economic Report of the President, 2002.

${ }^{34}$ Incorporating some period of post-bankruptcy unemployment would lower the average account balance for both choice and company stock match firms, and thus the difference in the distributions would not be substantially altered. Indeed, given that choice match firms have higher average bankruptcy rates, due to their higher stock price volatility, including a period of unemployment would increase the relative advantage of participating in a plan at a firm that matches in company stock.
} 
-100 percent; our implementation of bankruptcy effectively treats monthly return realizations beyond -65 to -70 percent as if they were -100 percent. Thus, the marginal effect of this "imposed" bankruptcy is not that large because the stock would have performed poorly anyway (i.e., whereas a -80 percent return wipes out four-fifths of the account balance in scenario 4 , it would lead to bankruptcy in scenario 5 and thus wipe out the entire company stock balance).

Another potential concern is that we draw from the distribution of historical returns in which there was a sizeable equity premium. There are numerous reasons to believe that the equity premium has fallen and that the equity premium going forward may be lower than it has been in the past (Fama and French, 2002; Blanchard, 1993; Campbell, 2001; Diamond 2001). To account for the possibility that the equity premium will be lower in the future, we reduce the historical gap between the equity return and Treasury bill rate of approximately eight percentage points to approximately four percentage points for our simulations. ${ }^{35}$

This four-percentage point cut, implemented in scenario 6, dramatically reduces expected retirement account balances, more so for company stock match firms since a larger part of their holdings are in equities. The median balance for the company stock match firms is $\$ 243,000$ (versus $\$ 465,000$ before the halving of the equity premium), just about equal to the median balance for the choice match firms of $\$ 244,000$. Thus, the company stock match exceeds the choice match only 49 percent of the time. ${ }^{36}$ As has been the case, the mean balance for the company stock match firm still exceeds that for the choice match firm, however it now does so by only 29 percent, compared to 41 percent before the reduction in the equity premium (scenario 4). When additional uncorrelated wealth of $\$ 250,000$ is assumed, the reduction of the equity premium reduces the CRRA at which participants are indifferent to match policy from 3.2 to 2.2.

The final simulation, scenario 7, combines the previous two scenarios - jointly allowing for bankruptcy and reducing the equity premium. Now the company stock match portfolio underperforms the choice match 55 percent of the time, and only individuals with CRRA of 2 or

\footnotetext{
${ }^{35}$ The equity premium reduction of 32.5 basis points per month is applied to all equity instruments, including large cap, small cap, company stock, and the equity portion of the balanced fund. We have not altered the return on the money market or bond investments, although in general equilibrium one might expect these returns to change as well if the equity premium is reduced. A reduction in the expected return of fixed-income securities as well would enhance the desirability of a match in company stock.

${ }^{36}$ The account balance at the company stock match firms exceeds than at the choice firms 70 percent of the time if there is no reduction in the historical equity premium and 49 percent of the time if there is a four-percentage point reduction in the equity premium. Assuming a two-percentage point reduction in the equity premium, consistent with Samwick and Skinner (2003), results in the company stock match plan accounts outperforming 57 percent of the time.
} 
less prefer the company stock match (again assuming $\$ 250,000$ of additional wealth). The simulations in scenarios 5 through 7 underscore that a lower equity premium is a greater source of risk to a match in company stock than firm bankruptcy.

An alternative way to examine the importance of the equity premium is to impose the restriction that choice firms provide their matching contributions entirely in the large-cap equity fund. While this scenario is of little real world relevance -- no firms do this because there is no advantage to restricting match choice except if it is in company stock -- this scenario helps to further quantify the role of the equity premium. In unreported analyses, we evaluated scenarios assuming that the "choice" firms actually matched with a large-cap equity fund. Not surprisingly, this approach reduces the desirability of the company stock match because the large-cap equity portfolio has less risk. When the choice match is directed into the S\&P 500, the balance at choice plans outperforms the balance at company stock match plans roughly threefifths of the time, versus about 30 percent of the time when the choice firm match was distributed evenly across all seven investment options. Once we incorporate bankruptcy risk and a lower equity premium, individuals with CRRA of 1.8 or less prefer the match to be in company stock, even if the "choice" match would all be in the S\&P 500 (assuming $\$ 250,000$ of additional wealth). As outside wealth rises to $\$ 1$ million, the indifference level of relative risk aversion rises to 3.7. These results underscore that from an employees' perspective, a company stock match is not the best way to increase the equity exposure of the 401(k) account; however, the employer has no incentive to restrict the match to an equity fund.

\section{Do Firms Choose the Appropriate Match Policy?}

Our earlier results suggest that the choice of employer match policy is negatively related to firm risk and is more likely if the firm also offered additional retirement benefits in the form of a DB plan. We hypothesized that these effects owed to fewer concerns by these firms that participants would have inadequate retirement wealth. To explore this hypothesis further, we consider two counterfactual scenarios that assess whether participants would have been better off if the firms had chosen the alternative match policy. That is, we test whether account balances at choice firms are higher with an unrestricted match (their actual policy) than with a company stock match (the counterfactual policy) for these same firms, and visa versa. The point of these comparisons is to see if firms appear to choose the employer match that provides the most favorable distribution of account balances given the firm's characteristics. 
We do these counterfactual exercises for the base case and the scenario allowing for bankruptcy risk and a reduced equity premium (scenario 7 in table 10). For the base case, we first simulate balances for choice match firms allowing an unrestricted match, their actual policy (column 1 in table 11), but then require the counterfactual that the employer match is in company stock (column 2 in table 11). Similarly, we simulate balances for company stock match firms first allowing these firms to make an unrestricted match (the counterfactual policy, column 3), and then requiring a match all in company stock (their actual policy, column 4). Results for scenario 7 are reported similarly in columns 5 to 8 .

Comparing columns 1 and 2, we find that the account balance would have been lower just over half the time (51 percent) if the choice match companies had been forced to match in company stock. Columns 3 and 4 show that the companies that actually do match in company stock end up with a higher account balance three-fifths of the time (59 percent) than if they would have offered an unrestricted match. This evidence is at least consistent with the notion that companies are selecting their match policy in a manner that takes into account the risk/reward trade-off for their employees.

Once one jointly considers the substantially reduced equity premium and the risk of bankruptcy, it is clear that the typical choice firm is making the "right" decision to offer an unrestricted match since the choice firm is relatively risky (columns 5 and 6). However, the evidence also suggests that the company stock match firms are forcing employees into an inferior distribution relative to if they had allowed choice for all but the most risk-tolerant employees. While forcing employees into company stock is less costly for the firms that actually do it than for the choice firms, it is nonetheless the case that, once one incorporates a reduced equity premium and the risk of bankruptcy, the comparison of the distributions is unfavorable to the company stock match. Naturally, therefore, the appropriateness of the company stock match policy is sensitive to the equity premium.

On net, the evidence is consistent with the idea that firms are partially sorting themselves based on how the match policy decision affects the distribution of employee retirement wealth. In all scenarios, the decision to match in company stock is a better decision for those that actually do the match in company stock than it would be for those that currently provide choice. D. What if Employees Do Not Diversify Their Own Contributions?

Up to this point, we have assumed that participants hold somewhat diversified portfolios 
because of their $1 / \mathrm{n}$ allocation rule for contributions. But, empirically, $1 / \mathrm{n}$ contribution allocations apply to the average investor, and we know from participant-level studies that while some $1 / \mathrm{n}$ investors exist, there are many who put all of their funds in a single asset (Agnew, 2002; Benartzi and Thaler, 2001; Holden and VanDerhei, 2001b).

To assess the desirability of a company stock match for participants who would otherwise not diversify their retirement account holdings, we present simulation results for a company stock match versus a choice match if employees invested only in a single asset. Table 12 presents statistics for retirement-age account balances for each asset separately, starting with company stock, allowing for bankruptcy risk and a reduction in the equity premium of four percentage points per year. It is assumed that when the match is unrestricted (i.e., choice), that the worker invests both employee and employer contributions in the one asset, and when the match is required to be in company stock, the employer contribution is invested in company stock, but the employee contribution is invested in the one asset.

Not surprisingly, an account that is fully concentrated in a single stock exposes the participant to considerable risk. However, when we compare results when participants put all of their assets in company stock (first pair of columns in table 12), risk averse employees would prefer the account at a company stock match firm over that at a choice match firm, reflecting the lower risk of company stock match firms.

Similarly, if participants concentrate their holdings in one of the other non-company stock assets, a company stock match will be preferred to a choice match that is invested in the same undiversified asset, except in the case of small-cap equities. When the match is in company stock, participants who would otherwise concentrate their and their employer's contributions in a fixed-income security (scenarios two through four), obtain exposure to equities and some diversification gains they otherwise would not receive. For example, although an inefficient means of obtaining equity exposure, most participants who would otherwise be concentrated in the money market fund are better off having one-third of total contributions directed toward company stock. Assuming $\$ 250,000$ of additional uncorrelated wealth, those with CRRA less than 11.1 prefer the company stock match.

On the other hand, if participants would otherwise concentrate investments in a small-cap equity fund, then the company stock match has little to offer in terms of added exposure to equities, so the distribution of account balances is less favorable to the company stock match. 
Since the beta on the size factor (small minus big) is substantially less than one (the median for company stock match firms is 0.28 ), adding company stock to a portfolio that is otherwise concentrated in small stocks does provide some diversification value in terms of reducing the risk associated with the size factor. However, this effect must be balanced against the increased idiosyncratic risk associated with a company stock match.

The results of our simulations, whether contributions are diversified or concentrated, suggest that sufficiently risk-tolerant participants generally would prefer a 401(k) plan at a firm that matches with company stock than a plan at a firm that provides an unrestricted match. This conclusion reflects two empirical findings. First, firms that match in company stock have lower idiosyncratic risk and lower bankruptcy risk than firms that allow match choice. Our results do not indicate that workers would want firms that currently provide an unrestricted match to switch to requiring that employer contributions be in company stock. Indeed, the significantly higher risk of firms that offer an unrestricted match would substantially increase the variance of account balances if the firm were to switch match policy, and only the most risk-tolerant employees would be better off from such a change.

Second, since firms do not have incentives to guide participants to equities other than company stock, the equity exposure obtained through a company stock match, while inefficient, may be better than the alternative asset composition under a choice match, particularly if participants stick with low-yielding default investment options. Choi, Laibson, Madrian, and Metrick (2001) report that $80 \%$ of participants accept both the default savings rate and the default investment fund (a money market or stable value fund) at firms that have automatic enrollment for their 401(k) plan. Further, even after three years, half of the plan participants subject to automatic enrollment continue to invest all of their contributions in the default fund. A more efficient means to provide such participants equity exposure would be to provide an employer match in a well-diversified stock fund. However, given the lack of incentive for employers to do this, a match in company stock, particularly at firms that provide other sources of retirement income and have lower risk, can be a second-best means of promoting greater retirement wealth accumulation.

\section{Conclusion and Policy Implications}

The increasing importance of $401(\mathrm{k})$ plans in providing for retirement has raised concerns 
about the financial security of future retirees. An especially important part of a 401(k) plan is whether the employer matching contributions are restricted to company stock or can instead be invested as the employee chooses. Match policy has a large effect on the amount of company stock in the retirement account because employer contributions are roughly one-third of total contributions, employees at firms that match in company stock tend to invest more of their own contributions into company stock, and participants rarely rebalance their portfolios to reduce the concentration in company stock. This paper studies why some firms match in company stock while others do not. Employers must trade off a number of costs and benefits that arise from requiring that employees hold their $401(\mathrm{k})$ match in company stock. This paper provides what is the first evidence on which of these costs and benefits appear to matter most to firms, and then explores the implications of match policy for employee retirement wealth.

Unlike stock option grants to non-executives, the firm's decision to match in company stock does not appear to be correlated with cash flow or with measures of the benefits of aligning incentives of employees and owners. Rather, consistent with the notion that firms consider the retirement security of their workers in making the match decision, we find that firms are more likely to provide the match in company stock if firm risk is low and employees are also covered by a defined benefit plan. We interpret these findings as consistent with firms considering the effect of match policy on the retirement security of plan participants, either because firms want to minimize the chance of being considered in violation of their fiduciary duties under ERISA or because employees at these firms more fully value company stock because of the lower firmspecific risk. We also find evidence that a company stock match is more likely if the firm does not have multiple classes of stock, which is an alternative mechanism to reduce hostile takeover attempts, and if the firm pays dividends, likely reflecting the potential tax deductions for dividends paid on match stock (although the dividend result is less robust).

We use simulation methods to assess the effect of match policy on the expected distribution of account balances at retirement for plan participants, incorporating the behavioral responses to match policy by participants as well as the characteristics of the firms offering the plan. Our results suggest that, for sufficiently risk-tolerant individuals, participating in a 401(k) plan at a company with a company stock match is often preferable to participating in a plan at a company with an unrestricted match, given the historical equity premium. This result is attributable to several factors. First, the firms that match in company stock have substantially 
lower bankruptcy risk and stock price volatility. Second, the match in company stock increases the equity exposure of participants, often by reducing the share of assets held in lower-return fixed-income securities. For example, after confirming that an employer match leads to participants contributing more of their own contributions to company stock, we show that about two-fifths of this boost in company stock purchases comes from a reduction in contributions to the safest asset, which is typically a money market fund. Lower administrative costs for company stock holdings also contribute to the desirability of a company stock match. However, a lower equity premium reduces the preference for a company stock match.

Disentangling the alternative hypotheses for firms' choice of match policy is important for guiding public policy. Our evidence that cash flow constraints are not important suggests that policy prescriptions to prohibit a match in company stock would be unlikely to lead to a less generous employer match, which might have been the case if these firms had no other means to contribute to the plan. However, if a firm matches in company stock to deter a takeover attempt by increasing the shares held in "friendly hands," then a cap on company stock may make offering an employer match less desirable for the firm. The lack of evidence supporting that a company stock match is provided for traditional equity incentive purposes suggests that a prohibition on a match in company stock is unlikely to lead firms to increase equity-based compensation to employees through other means, such as by granting more stock options.

Consistent with our empirical result that less risky firms match in company stock, we find evidence in our simulations that firms, on average, appear to sort themselves into a match policy in part based on the implications for participant retirement wealth. That is, the expected distribution of retirement wealth at firms that require the match in company stock generally dominates the distribution simulated under the counterfactual assumption that the same firms instead provided an unrestricted match. Thus while matching in company stock may not be the most efficient way to increase equity exposure, this result suggests that across-the-board limitations on a company stock match may not be appropriate for all firms. Only if we assume a significant cut in the equity premium or assume that the participant is already concentrated in a small-cap equity fund would a participant not prefer the company stock match.

A promising direction for future research is to consider the role of 401(k) plans in studies of stock based compensation for non-executives. Within 401(k) plans of firms that match in company stock, the number of shares held in the plans is comparable to the number of 
outstanding employee stock options held by non-executives. However, the firms that grant stock options appear to be very different than the firms that grant stock to their employees through their 401(k) plan. Moreover, 401(k) plans are more broad-based than stock option programs, suggesting that a lower-level worker at a profitable, dividend-paying industrial firm may have more exposure to company stock than a lower-level worker at a non-dividend-paying technology company. This suggests that it may be important to incorporate stock received through the 401(k) plan when studying stock-based compensation for non-executives. 


\section{References}

Agnew, Julie, 2002, Inefficient choices in 401(k) plans: Evidence from individual level data, Working paper, The College of William and Mary.

Agnew, Julie, Pierluigi Balduzzi, and Annika Sunden, 2003, Portfolio choice and trading in a large 401(k) plan, American Economic Review 93-1, 193-215.

Ameriks, John and Stephen Zeldes, 2001, How do household portfolio shares vary with age?, Working paper, Columbia University, December.

Beatty, Anne, 1995, The cash flow and informational effects of employee stock ownership plans, Journal of Financial Economics 38, 211-240.

Benartzi, Shlomo, 2001, Excessive extrapolation and the allocation of 401(k) accounts to company stock, Journal of Finance 56, 1747-64.

Benartzi, Shlomo and Richard H. Thaler, 2001, Naïve diversification strategies in retirement savings plans, American Economic Review 91-1, 79-98.

Blanchard, O.J., 1993, Movements in the equity premium, Brookings Papers on Economic Activity 2, 75-138.

Campbell, John, 2001, Forecasting US equity returns in the $21^{\text {st }}$ century, in Social Security Advisory Board, editor, Estimating the real rate of return on stocks over the long term, August, 3-10.

Carhart, Mark M., 1997, On persistence in mutual fund performance, Journal of Finance 52, 5782.

Choi, James, David Laibson, Brigitte Madrian, and Andrew Metrick, 2001, For better or for worse: Default effects and 401(K) savings behavior, NBER Working paper 8651, December.

Core, John E. and Wayne R. Guay, 2001, Stock option plans for non-executive employees, Journal of Financial Economics, 61, 253-287.

DeAngelo, H. and L. DeAngelo, 1985, Managerial ownership of voting rights: a study of public corporations with dual classes of common stock, Journal of Financial Economics 14, 33-69.

Demsetz, Harold and Kenneth Lehn, 1985, The structure of corporate ownership: causes and consequences, Journal of Political Economy 93(6), 1155-77.

Department of Labor, Employee Benefits Security Administration, 2001, Report of the working group on increasing pension coverage, participation and benefits, Nov. 13. 
Diamond, Peter, 2001, What stock market returns to expect for the future: an update, in Social Security Advisory Board, editor, Estimating the real rate of return on stocks over the long term, August, 11-16.

Even, William and David Macpherson, 2003 (a), The distributional consequences of the shift to defined contribution plans, Working paper, July.

Even, William and David Macpherson, 2003 (b), The causes and consequences of company stock holdings in pension funds, Working paper presented at Southern Economics meetings, November.

Fama, Eugene and Kenneth French, 2002, The equity premium, The Journal of Finance, 62, 637659.

Fama, Eugene and Kenneth French, 1993. Common risk factors in the return on bonds and stocks, Journal of Financial Economics 33, 3-53.

Holden, Sarah and VanDerhei, Jack, 2001 (a), 401(k) plan asset allocation, account balances, and loan activity in 2000, Investment Company Institute Perspective 7(5).

Holden, Sarah and VanDerhei, Jack, 2001 (b), The impact of employer-selected investment options on 401(k) plan participants' asset allocations: Preliminary findings, Working Paper, Investment Company Institute and Temple University.

Holmstrom, Bengt and Paul Milgrom, 1987, Aggregation and linearity in the provision of intertemporal incentives, Econometrica 55, 303-328.

Ibbotson Associates, 2002, SBBI (Stocks, bonds, bills, and inflation) 2002 yearbook: Market results for 1926-2001, Chicago, IL: Ibbotson Associates.

Iwry, Mark, 2003, Promoting 401(k) security, Tax policy Issues and Options, Urban-Brookings Tax Policy Center, September, No. 7.

Jensen, Michael C. and William H. Meckling, 1976, Theory of the firm: Managerial behavior, agency costs and ownership structure, Journal of Financial Economics 3(4), 305-360.

Lazear, Edward P., 1979, Why is there mandatory retirement? Journal of Political Economy, Vol. 87, 6 (December), 1261-84.

Lazear, Edward P., 1983, Pensions as severance pay, in Zvi Bodie, John B. Shoven, and David A. Wise, eds., Financial Aspects of the United States Pension System, Chicago: University of Chicago Press, 57-85.

Liang, Nellie and Scott Weisbenner, 2001, Who benefits from a bull market? An analysis of employee stock option grants and stock prices, Federal Reserve Board working paper 200157. 
Liang, Nellie and Scott Weisbenner, 2002, Investor behavior and the purchase of company stock in 401(k) plans - The importance of plan design, NBER working paper 9131.

Meulbroek, Lisa, 2002, Company stock in pension plans: How costly is it?, Working paper, Harvard University.

Mitchell, Olivia S. and Stephen Utkus, 2004, Lessons from behavioral finance for retirement plan design, in Olivia S. Mitchell and Stephen Utkus, eds., Pension design and structure: New Lessons from behavioral finance, Oxford, UK: Oxford University Press, forthcoming..

Munnell, Alicia H. and Annika Sunden, 2003, Coming up short: The challenge of 401(k) plans, Brookings Institution Press: Washington, D.C.

Myers, Stewart and Nicholas Majluf, 1984, Corporate financing and investment decisions when firms have information that investors do not have, Journal of Financial Economics 13(2), $182-221$.

Petersen, M.A., 1992, Pension reversions and worker-stockholder wealth transfers, Quarterly Journal of Economics, Aug., 219-239.

Poterba, James, Joshua Rauh, Steven Venti, and David Wise, 2003, Utility evaluation of risk in retirement saving accounts, NBER working paper 9892.

Profit Sharing/401(k) Council of America, 2002, $44^{\text {th }}$ Annual survey of profit sharing and 401(k) plans.

Purcell, Patrick, 2002, Employer stock in retirement plans: Investment risk and retirement security, CRS report for Congress, June.

Rauh, Joshua, 2003, Own company stock in defined contribution pension plans: A takeover defense?, Working Paper, MIT.

Samuelson, William and Richard Zeckhauser, 1988, Status quo bias in decision making, Journal of Risk and Uncertainty 1 (March), 7-59.

Samwick, Andrew and Jonathan Skinner, 2003, How will 401(k) pension plans affect retirement income?, American Economic Review, forthcoming.

Schultz, Ellen E., and Theo Francis, 2002, Hot tax break: 401(k)s - Why firms stuff plans with stock, Wall Street Journal, January.

Shivdasani, Anil, 1993, Board composition, ownership structure, and hostile takeovers, Journal of Accounting and Economics, 16, 167-198. 
Smith, Clifford W. and Ross Watts, 1992, The investment opportunity set and corporate financing, dividend and compensation policies, Journal of Financial Economics 32 (3) December, 262-92.

Standard \& Poor's, 2001, Ratings performance 2000: Default, transition, recovery, and spreads, January.

United States Department of Labor, Private Pension Plan Bulletin, Winter 2001-2002.

VanderHei, Jack, 2002, The role of company stock in 401(k) plans, Risk Management and Insurance Review 5 (1), 1-20.

Vanguard Group, 2003, Employer and Employee Attitudes Toward Company Stock in 401(k) Plans, October. 
Table 1: Sample Composition

\begin{tabular}{cc|ccc}
\hline Year & Number of observations & $\begin{array}{c}\text { Number of } \\
\text { years in sample }\end{array}$ & Number of firms & Number of observations \\
\hline 1991 & 49 & 1 & 195 & 195 \\
1992 & 174 & 2 & 204 & 408 \\
1993 & 288 & 3 & 179 & 537 \\
1994 & 338 & 4 & 113 & 452 \\
1995 & 432 & 5 & 84 & 420 \\
1996 & 537 & 6 & 73 & 438 \\
1997 & 597 & 7 & 63 & 441 \\
1998 & 635 & 8 & 29 & 232 \\
1999 & 89 & 9 & 4 & 36 \\
2000 & 40 & 10 & 2 & 20 \\
TOTAL & $\mathbf{3 1 7 9}$ & TOTAL & $\mathbf{9 4 6}$ & $\mathbf{3 1 7 9}$ \\
\hline
\end{tabular}

Data collected for all U.S. companies listed in Compustat any year from 1993 to 1999 that filed an 11-k at least once during 1994-2001. See text for further details. 
Table 2a: Characteristics of 1998 Sample, S\&P 1500, and Public Firms

\begin{tabular}{|c|c|c|c|}
\hline & 1998 Sample & S\&P 1500 & Public Firms \\
\hline \multicolumn{4}{|l|}{ Market Value (\$ millions) } \\
\hline Mean & 5,435 & 7,283 & 2,438 \\
\hline Median & 734 & 1,329 & 192 \\
\hline$\left[10^{\text {th }} \%-90^{\text {th }} \%\right]$ & {$[69-9,574]$} & {$[238-14,211]$} & {$[26-3,260]$} \\
\hline \multicolumn{4}{|l|}{ Employees (000s) } \\
\hline Mean & 13.1 & 19.9 & 5.4 \\
\hline Median & 4.3 & 6.6 & 0.5 \\
\hline$\left[10^{\text {th }} \%-90^{\text {th }} \%\right]$ & {$[0.5-30.3]$} & {$[0.9-45]$} & {$[0.02-10.2]$} \\
\hline Member of S\&P $1500(\%)$ & 51 & 100 & 20 \\
\hline Technology Sector (\%) & 15 & 19 & 24 \\
\hline Repurchase yield $(\%$, mean $)$ & 1.76 & 1.82 & 1.77 \\
\hline
\end{tabular}

Data are from Compustat. The share repurchase yield is the amount spent to repurchase shares divided by the average of the beginning-and end-of-year market value. Public firms include 7,501 U.S. firms.

Table 2b: Aggregate 401-k Plan Assets and Contributions for 1998 Sample, Public Firms, and All Firms

\begin{tabular}{lccc}
\hline & 1998 Sample: 635 firms & Public Firms & All Firms \\
\hline Total 401-k Assets (\$ billions) & 264 & 698 & 1541 \\
Total 401-k Assets in Company Stock (\$ billions) & 97 & 273 & 273 \\
Employee and Employer Contributions (\$ billions) & 15.2 & 49.2 & 134.7 \\
Contributions in Company Stock (\$ billions) & 4.9 & NA & NA \\
\hline
\end{tabular}

Data on 401-k assets for public firms are from 19985500 filings with the Department of Labor. Data for all firms (public and private) are estimated by the Department of Labor. Company stock for public firms and all firms excludes stock indirectly held in trusts and pooled accounts. Employer contributions constitute 30 percent of total contributions for the 1998 sample and 31percent for all public firms. 
Table 3: Relation between Match Policy and 401(k) Asset Allocation, Full Sample

\begin{tabular}{|c|c|c|c|c|c|c|}
\hline & \multicolumn{3}{|c|}{ Mean } & \multicolumn{3}{|c|}{ Median } \\
\hline & $\begin{array}{l}\text { Match All } \\
\text { Co. Stock } \\
\end{array}$ & $\begin{array}{l}\text { Match } \\
\text { Choice }\end{array}$ & Difference & $\begin{array}{l}\text { Match All } \\
\text { Co. Stock } \\
\end{array}$ & $\begin{array}{l}\text { Match } \\
\text { Choice }\end{array}$ & Difference \\
\hline \multicolumn{7}{|l|}{ Full Sample 1991-2000 (3,179 observations) } \\
\hline (1) Percent of Firm-year Observations & 39.3 & 60.7 & & 39.3 & 60.7 & \\
\hline (2) Percent of Employee Contributions Invested in Co. Stock & 25.0 & 15.5 & $9.5^{* * *}$ & 19.9 & 11.3 & $8.6^{* * *}$ \\
\hline (3) Percent of Total Contributions Invested in Co. Stock & 45.5 & 17.0 & $28.5^{* * *}$ & 43.8 & 12.2 & $31.6^{* * *}$ \\
\hline (4) Percent of Total Contributions Required in Co. Stock & 28.1 & 1.8 & $26.4^{* * *}$ & 26.8 & 0.0 & $26.8^{* * *}$ \\
\hline (5) Percent of Total Assets Invested in Company Stock & 42.4 & 18.2 & $24.2^{* * *}$ & 39.7 & 11.7 & $28.0^{* * *}$ \\
\hline (6) Ratio of Total Employer to Total Employee Contributions & 46.0 & 52.8 & -6.8 & 36.7 & 39.7 & $-3.0^{* * *}$ \\
\hline (7) Percent of Total Firm Stock Held in 401(k) Plan & 4.5 & 1.6 & $2.9^{* * *}$ & 2.9 & 0.8 & $2.1^{* * *}$ \\
\hline (8) Percent of Total Firm Stock Used for 401(k) Contributions & 0.56 & 0.20 & $0.36^{* * *}$ & 0.36 & 0.11 & $0.25^{* * *}$ \\
\hline (9) Number of Investment Options Offered & 6.8 & 8.0 & $-1.2^{* * *}$ & 6.0 & 7.0 & $-1.0^{* * *}$ \\
\hline \multicolumn{7}{|l|}{ 1997-98 Sample Merged with Form 5500 Data (906 obs.) } \\
\hline (10) Participants in 401(k) plan & 6398 & 5454 & 944 & 2552 & 1786 & $761^{* * *}$ \\
\hline (11) Percent of Total Firm Employees Participating in Plan & 69.5 & 66.3 & 3.2 & 56.2 & 61.2 & $-4.9^{*}$ \\
\hline (12) Total Employee Contributions per Participant (\$) & 3,104 & 2,773 & $330^{* *}$ & 2,965 & 2,601 & $364^{* * *}$ \\
\hline (13) Total Employer Contributions per Participant (\$) & 1,243 & 1353 & -110 & 1020 & 1097 & -77 \\
\hline (14) Account Balance per Participant (\$) & 60,600 & 43,220 & $17,380^{* * *}$ & 43,180 & 34,791 & 8,389 \\
\hline (15) Balance in Company Stock per Participant (\$) & 27,107 & 7,407 & $19,700^{* * *}$ & 15,430 & 3,194 & $12,236^{* * *}$ \\
\hline
\end{tabular}

${ }^{* * *},{ }^{* *},{ }^{*}$ denote difference is significant at the 1 percent, 5 percent, and 10 percent levels, respectively. 
Table 4: Regression of Match Policy on Firm Characteristics

\begin{tabular}{|c|c|c|c|c|c|c|c|c|c|c|c|}
\hline & (1) & (2) & (3) & (4) & (5) & (6) & (7) & (8) & (9) & (10) & (11) \\
\hline Defined Benefit Plan? & $\begin{array}{l}22.3^{* * *} \\
(3.3)\end{array}$ & & & & & & & & & & $\begin{array}{l}21.3^{* * *} \\
(4.9)\end{array}$ \\
\hline Monthly std. dev. of returns & & $\begin{array}{l}-130.2^{* * *} \\
(48.4)\end{array}$ & & & & & & & & & $\begin{array}{r}2.7 \\
(69.1)\end{array}$ \\
\hline Monthly idiosyncratic risk & & & $\begin{array}{l}-125.3^{* * *} \\
(48.8)\end{array}$ & & & & & & & & \\
\hline Beta & & & $\begin{array}{l}-1.9 \\
(2.7)\end{array}$ & & & & & & & & \\
\hline Investment grade debt? & & & & $\begin{array}{l}18.1^{* * *} \\
(3.6)\end{array}$ & & & & & & & $\begin{array}{l}11.1^{* *} \\
(5.6)\end{array}$ \\
\hline Cash Flow-to-Assets & & & & & $\begin{array}{r}8.6 \\
(14.3)\end{array}$ & & & & & & \\
\hline Maximum (CF/Assets, 0) & & & & & & $\begin{array}{r}33.1 \\
(18.1)\end{array}$ & & & & & $\begin{array}{r}51.4^{*} \\
(31.5)\end{array}$ \\
\hline Minimum (CF/Assets, 0) & & & & & & $\begin{array}{l}-20.2^{* * *} \\
(8.0)\end{array}$ & & & & & $\begin{array}{r}-10.8 \\
(74.1)\end{array}$ \\
\hline Dividend Yield (in \%) & & & & & & & $\begin{array}{l}3.3^{* * *} \\
(1.0)\end{array}$ & & & & $\begin{array}{r}-1.0 \\
(1.4)\end{array}$ \\
\hline Market-to-book ratio & & & & & & & & $\begin{array}{r}-0.5 \\
(1.4)\end{array}$ & & & $\begin{array}{r}0.4 \\
(1.8)\end{array}$ \\
\hline Log (Employees) & & & & & & & & & $\begin{array}{l}1.9^{*} \\
(1.1)\end{array}$ & & $\begin{array}{r}-1.1 \\
(3.0)\end{array}$ \\
\hline Multiple classes of stock? & & & & & & & & & & $\begin{array}{c}-17.0^{* *} \\
(7.0)\end{array}$ & $\begin{array}{r}-15.0 \\
(11.0)\end{array}$ \\
\hline Past 5-year stock return & & & & & & & & & & & $\begin{array}{r}-0.3 \\
(0.3)\end{array}$ \\
\hline S\&P 500? & & & & & & & & & & & $\begin{array}{r}4.9 \\
(6.1)\end{array}$ \\
\hline Log (Assets) & & & & & & & & & & & $\begin{array}{r}-4.3 \\
(3.0)\end{array}$ \\
\hline Dummies for Firm Age & No & No & No & No & No & No & No & No & No & No & $\mathrm{Y},(\mathrm{p}=0.09)$ \\
\hline 2-digit Industry effects & No & No & No & No & No & No & No & No & No & No & $\mathrm{Y},(\mathrm{p}=0.00)$ \\
\hline Year effects & Yes & Yes & Yes & Yes & Yes & Yes & Yes & Yes & Yes & Yes & $\mathrm{Y},(\mathrm{p}=0.00)$ \\
\hline $\mathrm{R}^{2}$ & 0.0708 & 0.0311 & 0.0312 & 0.0521 & 0.0209 & 0.0246 & 0.0359 & 0.0208 & 0.0227 & 0.0261 & 0.2267 \\
\hline Number of observations & 3,179 & 2,679 & 2,679 & 3,179 & 3,098 & 3,098 & 3,170 & 3,141 & 2,993 & 3,179 & 2,089 \\
\hline
\end{tabular}


Table 5: Regression of Match Policy on Firm Characteristics, Focus on Broad-Based Plans

\begin{tabular}{|c|c|c|c|c|c|c|}
\hline & \multicolumn{3}{|c|}{ Full Sample } & \multicolumn{3}{|c|}{$\begin{array}{c}\text { Sample Restricted to Broad-Based DC and DB } \\
\text { Plans (Participants in DC/DB Plan are at least } \\
50 \% \text { of Total Firm Employees), } 1997 \text { - } 1998\end{array}$} \\
\hline & (1) & (2) & (3) & (4) & (5) & (6) \\
\hline Defined Benefit Plan & $\begin{array}{l}22.3^{* * *} \\
(3.3)\end{array}$ & $\begin{array}{l}31.9^{* * *} \\
(4.3)\end{array}$ & $\begin{array}{l}32.1^{* * *} \\
(6.0)\end{array}$ & $\begin{array}{l}26.7^{* * *} \\
(5.9)\end{array}$ & $\begin{array}{l}40.9^{* * *} \\
(11.3)\end{array}$ & $\begin{array}{c}25.9^{*} \\
(15.9)\end{array}$ \\
\hline $\begin{array}{l}\text { Ratio of Match to } \\
\text { Own Contributions }\end{array}$ & & $\begin{array}{r}-0.6 \\
(2.4)\end{array}$ & $\begin{array}{r}-0.2 \\
(1.5)\end{array}$ & & $\begin{array}{r}-6.3 \\
(4.0)\end{array}$ & $\begin{array}{l}-15.4^{*} \\
(8.0)\end{array}$ \\
\hline $\begin{array}{l}\text { DB Plan* } \\
\text { Ratio of Match to Own }\end{array}$ & & $\begin{array}{l}-19.1^{* * *} \\
(5.4)^{4}\end{array}$ & $\begin{array}{l}-21.3^{* * *} \\
(7.0)\end{array}$ & & $\begin{array}{r}-31.3 \\
(22.3)\end{array}$ & $\begin{array}{r}-15.5 \\
(29.0)\end{array}$ \\
\hline Year Effects & Yes & Yes & Yes & Yes & Yes & Yes \\
\hline Other Covariates & No & No & Yes & No & No & Yes \\
\hline $\mathrm{R}^{2}$ & 0.0708 & 0.0851 & 0.2354 & 0.0758 & 0.0933 & 0.3698 \\
\hline No. of observations & 3,179 & 3,087 & 2,020 & 430 & 418 & 288 \\
\hline
\end{tabular}

Coefficient estimates (standard errors) from regressions of whether the employer match is required to all be in company stock on firm explanatory variables. The match policy regressions are estimated using firm-year observations where the employer made contributions to the plan. Other covariates include all the variables included in the table 4, column 11 regression. Standard error calculations in the pooled cross-section regressions allow for heteroskedasticity as well as correlation across observations of the same firm.

${ }^{* * *},{ }^{* *},{ }^{*}$ denote significance at the 1 percent, 5 percent, and 10 percent levels, respectively. 
Table 6: Survey Responses of Firms to Costs and Benefits of Match Policy

\begin{tabular}{|c|c|c|c|}
\hline & \multicolumn{3}{|c|}{ Average Response $(10=$ agree completely, $1=$ disagree completely } \\
\hline & $\begin{array}{c}\text { Match All } \\
\text { Company Stock }\end{array}$ & Match Choice & Difference \\
\hline \multicolumn{4}{|c|}{ Costs of company stock match: Making employer contributions in company stock is a bad idea because } \\
\hline It reduces diversification for participant accounts & 5.2 & 7.6 & $-2.4^{* * *}$ \\
\hline It raises fiduciary risk and the chances of lawsuits & 4.6 & 6.5 & $-1.9^{* * *}$ \\
\hline It is too complicated legally & 2.8 & 3.5 & -0.7 \\
\hline \multicolumn{4}{|c|}{ Benefits of company stock match: Making employer contributions in company stock is a good idea because } \\
\hline $\begin{array}{l}\text { Company realizes benefits from employee stock } \\
\text { ownership }\end{array}$ & 8.0 & 4.9 & $3.1^{* * *}$ \\
\hline It generates tax benefits & 6.1 & 4.9 & 1.2 \\
\hline It means more shares of stock in friendly hands & 5.9 & 4.3 & $1.6^{* * *}$ \\
\hline It saves company cash & 4.8 & 4.3 & 0.5 \\
\hline
\end{tabular}

Source: The Vanguard Group (2003). Results based on survey of 76 firms.

${ }^{* * *}$ denotes difference is significant at the 1 percent level. 
Table 7: Regression of Percent of Employee Contributions in Company Stock, Money Market, and Other Options on Plan Characteristics, Past Asset Returns, and Firm Characteristics

\begin{tabular}{|c|c|c|c|c|c|c|c|c|}
\hline \multirow{3}{*}{$\begin{array}{l}\text { Variable } \\
\text { Match required to be in company stock? }\end{array}$} & \multirow{2}{*}{\multicolumn{2}{|c|}{$\begin{array}{l}\text { Percent of Employee } \\
\text { Contributions } \\
\text { in Company Stock }\end{array}$}} & \multirow{2}{*}{\multicolumn{2}{|c|}{$\begin{array}{l}\text { Percent of Employee } \\
\text { Contributions } \\
\text { in Money Market }\end{array}$}} & \multicolumn{4}{|c|}{ Percent of Employee Contributions in Other Options } \\
\hline & & & & & \multicolumn{2}{|c|}{ Average per option } & \multicolumn{2}{|c|}{ Other options in total } \\
\hline & $\begin{array}{c}8.1^{* * * k} \\
(1.2)\end{array}$ & $\begin{array}{c}6.9^{* * *} \\
(1.3)\end{array}$ & $\begin{array}{l}-2.9^{* * * k} \\
(0.9)\end{array}$ & $\begin{array}{l}-2.8^{* * *} \\
(1.1)\end{array}$ & $\begin{array}{l}-1.6^{* * *} \\
(0.4)\end{array}$ & $\begin{array}{l}-1.2^{* * *} \\
(0.4)\end{array}$ & $\begin{array}{l}-5.5^{* * * k} \\
(1.2)\end{array}$ & $\begin{array}{l}-4.2^{* * k} \\
(1.3)\end{array}$ \\
\hline 1 / \# of investment options & $\begin{array}{l}79.8^{* * *} \\
(8.6)\end{array}$ & $\begin{array}{c}98.3^{* * *} \\
(12.4)\end{array}$ & $\begin{array}{l}84.6^{* * *} \\
(7.5)\end{array}$ & $\begin{array}{c}52.5^{\text {*** }} \\
(10.7)\end{array}$ & $\begin{array}{l}82.4^{* * *} \\
(4.3)\end{array}$ & $\begin{array}{l}77.9^{* * *} \\
(5.2)\end{array}$ & $\begin{array}{c}-177.0^{* * *} \\
(7.5)\end{array}$ & $\begin{array}{l}-167.6^{* * *} \\
(10.0)\end{array}$ \\
\hline Safest option is GIC (rather than money market)? & & & $\begin{array}{l}10.3^{* * *} \\
(0.9)\end{array}$ & $\begin{array}{l}11.2^{* * *} \\
(1.1)\end{array}$ & & & & \\
\hline Monthly standard deviation of past stock returns & & $\begin{array}{l}-33.8^{* *} \\
(14.5)\end{array}$ & & $\begin{array}{c}27.8^{* *} \\
(13.2)\end{array}$ & & $\begin{array}{r}5.6 \\
(5.1)\end{array}$ & & $\begin{array}{r}17.8 \\
(15.1)\end{array}$ \\
\hline Own Company Stock return over past five years & & $\begin{array}{r}0.5 \\
(0.3)\end{array}$ & & $\begin{array}{r}-0.1 \\
(0.1)\end{array}$ & & $\begin{array}{r}-0.1 \\
(0.1)\end{array}$ & & $\begin{array}{c}-0.4^{*} \\
(0.2)\end{array}$ \\
\hline Value-Weighted Market return over past five years & & $\begin{array}{r}-1.1 \\
(0.9)\end{array}$ & & $\begin{array}{l}-4.8^{* * *} \\
(0.9)\end{array}$ & & $\begin{array}{c}0.5^{*} \\
(0.3)\end{array}$ & & $\begin{array}{l}5.2^{* * *} \\
(1.0)\end{array}$ \\
\hline Treasury Bill return over past five years & & $\begin{array}{l}-24.7^{* *} \\
(11.6)\end{array}$ & & $\begin{array}{l}78.8^{* * *} \\
(9.5)\end{array}$ & & $\begin{array}{l}-12.5^{* * *} \\
(4.3)\end{array}$ & & $\begin{array}{l}-49.4^{* * *} \\
(10.5)\end{array}$ \\
\hline Gov't Bond return over past five years & & $\begin{array}{r}-0.6 \\
(1.6)\end{array}$ & & $\begin{array}{c}2.7^{*} \\
(1.4)\end{array}$ & & $\begin{array}{r}0.8 \\
(0.6)\end{array}$ & & $\begin{array}{r}-2.1 \\
(1.7)\end{array}$ \\
\hline Market-to-book ratio & & $\begin{array}{l}1.3^{* * *} \\
(0.4)\end{array}$ & & $\begin{array}{r}-0.1 \\
(0.4)\end{array}$ & & $\begin{array}{l}-0.5^{* * *} \\
(0.2)\end{array}$ & & $\begin{array}{l}-1.0^{* *} \\
(0.5)\end{array}$ \\
\hline Log (Assets) & & $\begin{array}{l}2.6^{* * *} \\
(0.4)\end{array}$ & & $\begin{array}{c}0.8^{* *} \\
(0.4)\end{array}$ & & $\begin{array}{l}-0.8^{* * *} \\
(0.1)\end{array}$ & & $\begin{array}{l}-3.4^{* * *} \\
(0.4)\end{array}$ \\
\hline Constant & $\begin{array}{l}3.1^{* *} \\
(1.3)\end{array}$ & $\begin{array}{l}-9.1^{* *} \\
(3.9)\end{array}$ & $\begin{array}{r}0.8 \\
(1.1)\end{array}$ & $\begin{array}{l}-21.0^{* * *} \\
(3.9)\end{array}$ & $\begin{array}{l}2.0^{* * *} \\
(0.6)\end{array}$ & $\begin{array}{l}10.9^{* * *} \\
(1.5)\end{array}$ & $\begin{array}{l}92.9^{* * *} \\
(1.3)\end{array}$ & $\begin{array}{c}124.3^{* * *} \\
(4.3)\end{array}$ \\
\hline $\mathrm{R}^{2}$ & 0.1830 & 0.3059 & 0.2729 & 0.3707 & 0.4766 & 0.5082 & 0.3339 & 0.4959 \\
\hline Number of observations & 3,133 & 2,207 & 3,133 & 2,207 & 3,117 & 2,196 & 3,117 & 2,196 \\
\hline
\end{tabular}

Coefficient estimates (standard errors) from regressions of the percent of employee contributions allocated to various investment options on pension plan characteristics, past asset returns, and firm characteristics. Standard error calculations in the pooled cross-section regressions allow for heteroskedasticity as well as correlation across observations of the same firm.

${ }^{* * *},{ }^{* *},{ }^{*}$ denote significance at the 1 percent, 5 percent, and 10 percent levels, respectively. 
Table 8: Relation between Match Policy and Stock Return/Risk, Full Sample

\begin{tabular}{|c|c|c|c|c|c|c|}
\hline & \multicolumn{3}{|c|}{ Mean } & \multicolumn{3}{|c|}{ Median } \\
\hline & $\begin{array}{l}\text { Match All } \\
\text { Co. Stock } \\
293 \text { firms }\end{array}$ & $\begin{array}{l}\text { Match Choice } \\
574 \text { firms }\end{array}$ & Difference & $\begin{array}{l}\text { Match All } \\
\text { Co. Stock } \\
293 \text { firms }\end{array}$ & $\begin{array}{l}\text { Match Choice } \\
574 \text { firms }\end{array}$ & Difference \\
\hline Average Monthly Return (in \%) & 1.58 & 1.60 & -0.02 & 1.51 & 1.53 & -0.02 \\
\hline Average Monthly Excess Return (in \%) & 0.32 & 0.29 & 0.04 & 0.32 & 0.25 & 0.07 \\
\hline Market (market minus risk-free rate) Beta & 0.98 & 1.04 & -0.06 & 1.01 & 1.02 & -0.01 \\
\hline Size (small minus big) Beta & 0.37 & 0.59 & $-0.22^{* * *}$ & 0.28 & 0.50 & $-0.22^{* * *}$ \\
\hline Book-to-Market (high minus low) Beta & 0.47 & 0.53 & -0.06 & 0.55 & 0.61 & -0.06 \\
\hline Momentum (up minus down) Beta & -0.17 & -0.18 & 0.01 & -0.10 & -0.12 & 0.02 \\
\hline Standard Deviation of Monthly Returns (\%) & 11.4 & 13.0 & $-1.6^{* * *}$ & 9.9 & 11.9 & $-2.0^{* * *}$ \\
\hline Monthly Idiosyncratic Risk (in \%) & 10.1 & 11.6 & $-1.5^{* * *}$ & 8.6 & 10.7 & $-2.1^{* * *}$ \\
\hline
\end{tabular}

The average monthly excess return and idiosyncratic risk are calculated from a four-factor (i.e., market, size, book-to-market, and momentum) model proposed by Carhart (1997).

${ }_{* * * *}^{* *},{ }^{*}$ denote difference is significant at the 1 percent, 5 percent, and 10 percent levels, respectively. 
Table 9: Distribution of 401(k) Plan Assets by Match Policy and Firm Characteristics

\begin{tabular}{|c|c|c|c|c|c|c|}
\hline & \multicolumn{2}{|c|}{ Base Case } & \multicolumn{2}{|c|}{ Vary Match Policy } & \multicolumn{2}{|c|}{ Vary Firm Characteristics } \\
\hline & $\begin{array}{l}\text { Choice Firm \& } \\
\text { Choice Match }\end{array}$ & $\begin{array}{l}\text { Co. Stock Firm \& } \\
\text { Co. Stock Match }\end{array}$ & $\begin{array}{l}\text { Co. Stock Firm \& } \\
\text { Choice Match }\end{array}$ & $\begin{array}{l}\text { Co. Stock Firm \& } \\
\text { Co. Stock Match }\end{array}$ & $\begin{array}{l}\text { Choice Firm \& } \\
\text { Co. Stock Match }\end{array}$ & $\begin{array}{l}\text { Co. Stock Firm \& } \\
\text { Co. Stock Match }\end{array}$ \\
\hline$\%$ higher wealth & 31 & 69 & 41 & 59 & 12 & 88 \\
\hline \multicolumn{7}{|c|}{ Account Balance at Age 62 (\$000s) } \\
\hline Mean & 962 & 1,223 & 898 & 1,223 & 1,411 & 1,223 \\
\hline $1^{\text {st }} \%$ & 131 & 109 & 135 & 109 & 102 & 109 \\
\hline $10^{\text {th }} \%$ & 203 & 186 & 209 & 186 & 169 & 186 \\
\hline $25^{\text {th }} \%$ & 285 & 279 & 296 & 279 & 252 & 279 \\
\hline $50^{\text {th }} \%$ & 464 & 490 & 488 & 490 & 461 & 490 \\
\hline $75^{\text {th }} \%$ & 868 & 1,028 & 881 & 1,028 & 972 & 1,028 \\
\hline $90^{\text {th }} \%$ & 1,801 & 2,258 & 1,713 & 2,258 & 2,377 & 2,258 \\
\hline
\end{tabular}

Constant Relative Risk Aversion such that Indifferent Across Firms and/or Match Policy, Additional Uncorrelated Wealth (\$000s)

\begin{tabular}{l|c|c|c}
\hline & Prefer co. stock match if CRRA $<\mathbf{X}$ & Prefer co. stock match if CRRA $<$ X & Prefer co. stock firm if CRRA $>$ X \\
\hline 0 & 1.8 & 1.5 & 0.6 \\
250 & 2.9 & 2.3 & 0.6 \\
500 & 4.0 & 3.0 & 0.7 \\
1000 & 6.1 & 4.3 & 0.8 \\
\hline
\end{tabular}

Source: Authors' calculations as described in text. 
Table 10: Distribution of 401(k) Plan Assets by Match Policy Under Alternative Scenarios

\begin{tabular}{|c|c|c|c|c|c|c|c|c|c|c|c|c|c|c|}
\hline & \multicolumn{2}{|c|}{ (1) } & \multicolumn{2}{|c|}{$\begin{array}{c}\text { (2) } \\
\text { (1) plus } \\
\text { administrative } \\
\text { costs }\end{array}$} & \multicolumn{2}{|c|}{$\begin{array}{l}\text { (3) } \\
\text { (2) plus match in } \\
\text { co. stock boosts } \\
\text { own contr. to } \\
\text { company stock }\end{array}$} & \multicolumn{2}{|c|}{$\begin{array}{l}\text { (4) } \\
\text { (3) plus firms that } \\
\text { match in } \\
\text { co. stock offer } \\
\text { one less option }\end{array}$} & \multicolumn{2}{|c|}{$\begin{array}{l}\text { (5) } \\
\text { (4) plus risk of } \\
\text { firm going } \\
\text { bankrupt }\end{array}$} & \multicolumn{2}{|c|}{$\begin{array}{c}\text { (6) } \\
\text { (4) plus lower } \\
\text { equity premium } \\
\text { by } 0.325 \% \\
\text { per month }\end{array}$} & \multicolumn{2}{|c|}{\begin{tabular}{|c} 
(7) \\
(4) plus bankruptcy \\
risk and lower \\
equity premium
\end{tabular}} \\
\hline & Choice & $\begin{array}{l}\text { Co. } \\
\text { Stock } \\
\end{array}$ & Choice & $\begin{array}{c}\text { Co. } \\
\text { Stock }\end{array}$ & Choice & $\begin{array}{l}\text { Co. } \\
\text { Stock }\end{array}$ & Choice & $\begin{array}{l}\text { Co. } \\
\text { Stock }\end{array}$ & Choice & $\begin{array}{l}\text { Co. } \\
\text { Stock }\end{array}$ & Choice & $\begin{array}{c}\text { Co. } \\
\text { Stock }\end{array}$ & Choice & $\begin{array}{c}\text { Co. } \\
\text { Stock }\end{array}$ \\
\hline $\begin{array}{l}\% \text { times have } \\
\text { higher wealth }\end{array}$ & 31 & 69 & 28 & 72 & 34 & 66 & 30 & 70 & 34 & 66 & 51 & 49 & 55 & 45 \\
\hline
\end{tabular}

\begin{tabular}{|c|c|c|c|c|c|c|c|c|c|c|c|c|c|c|}
\hline Mean & 962 & 1,223 & 894 & 1,178 & 894 & 1,242 & 894 & 1,262 & 872 & 1,229 & 406 & 523 & 399 & 512 \\
\hline $1^{\text {st }} \%$ & 131 & 109 & 124 & 103 & 124 & 98 & 124 & 96 & 123 & 94 & 101 & 74 & 100 & 73 \\
\hline $5^{\text {th }} \%$ & 172 & 151 & 161 & 143 & 161 & 139 & 161 & 137 & 160 & 135 & 122 & 96 & 122 & 95 \\
\hline $10^{\text {th }} \%$ & 203 & 186 & 190 & 176 & 190 & 171 & 190 & 170 & 189 & 167 & 138 & 113 & 137 & 112 \\
\hline $25^{\text {th }} \%$ & 285 & 279 & 267 & 265 & 267 & 263 & 267 & 260 & 263 & 249 & 174 & 155 & 173 & 149 \\
\hline $50^{\text {th }} \%$ & 464 & 490 & 431 & 463 & 431 & 465 & 431 & 465 & 427 & 445 & 244 & 243 & 244 & 235 \\
\hline $75^{\text {th }} \%$ & 868 & 1,028 & 798 & 981 & 798 & 1,014 & 798 & 1,021 & 786 & 1,016 & 390 & 454 & 385 & 454 \\
\hline $90^{\text {th }} \%$ & 1,801 & 2,258 & 1,648 & 2,165 & 1,648 & 2,278 & 1,648 & 2,308 & 1,582 & 2,253 & 706 & 927 & 679 & 926 \\
\hline $95^{\text {th }} \%$ & 2,864 & 3,767 & 2,647 & 3,638 & 2,647 & 3,855 & 2,647 & 3,934 & 2,548 & 3,845 & 1,044 & 1,492 & 1,022 & 1,483 \\
\hline $99^{\text {th }} \%$ & 8,073 & 12,135 & 7,502 & 11,869 & 7,502 & 12,828 & 7,502 & 13,180 & 7,157 & 12,387 & 2,721 & 4,703 & 2,635 & 4,665 \\
\hline
\end{tabular}

Constant Relative Risk Aversion such that Indifferent Across Match Policy, Additional Uncorrelated Wealth (\$000s), Prefer Company Stock Match if CRRA < X

\begin{tabular}{|c|c|c|c|c|c|c|c|}
\hline 0 & 1.8 & 2.0 & 1.9 & 1.9 & 1.7 & 1.2 & 1.2 \\
\hline 250 & 2.9 & 3.5 & 3.3 & 3.2 & 2.7 & 2.2 & 2.0 \\
\hline 500 & 4.0 & 4.9 & 4.5 & 4.3 & 3.7 & 3.1 & 2.8 \\
\hline 1000 & 6.1 & 7.6 & 7.0 & 6.7 & 5.5 & 4.8 & 4.3 \\
\hline
\end{tabular}

Source: Authors' calculations as described in text. 
Table 11: Distribution of 401(k) Plan Assets Under Firm's Own Match Policy and Counterfactual Match Policy

\begin{tabular}{|c|c|c|c|c|c|c|c|c|}
\hline & \multicolumn{4}{|c|}{ Base Case } & \multicolumn{4}{|c|}{ Add Lower Equity Premium and Bankruptcy } \\
\hline & \multicolumn{2}{|c|}{ Choice Firm } & \multicolumn{2}{|c|}{ Company Stock Firm } & \multicolumn{2}{|c|}{ Choice Firm } & \multicolumn{2}{|c|}{ Company Stock Firm } \\
\hline & Choice Match Co. & o. Stock Match & Choice Match & Co. Stock Match & Choice Match Co. & Stock Match & Choice Match & Co. Stock Match \\
\hline$\%$ higher wealth & 51 & 49 & & & 65 & 35 & & \\
\hline \% higher wealth & & & 41 & 59 & & & 59 & 41 \\
\hline$\%$ higher wealth & 31 & & & 69 & 55 & & & 45 \\
\hline \multicolumn{9}{|c|}{ Account Balance at Age $62(\$ 000$ s) } \\
\hline Mean & 962 & 1,411 & 898 & 1,223 & 399 & 573 & 380 & 512 \\
\hline $1^{\text {st }} \%$ & 131 & 102 & 135 & 109 & 100 & 69 & 102 & 73 \\
\hline $5^{\text {th }} \%$ & 172 & 140 & 177 & 151 & 122 & 89 & 124 & 95 \\
\hline $10^{\text {th }} \%$ & 203 & 169 & 209 & 186 & 137 & 103 & 140 & 112 \\
\hline $25^{\text {th }} \%$ & 285 & 252 & 296 & 279 & 173 & 139 & 177 & 149 \\
\hline $50^{\text {th }} \%$ & 464 & 461 & 488 & 490 & 244 & 222 & 247 & 235 \\
\hline $75^{\text {th }} \%$ & 868 & 972 & 881 & 1,028 & 385 & 430 & 392 & 454 \\
\hline $90^{\text {th }} \%$ & 1,801 & 2,377 & 1,713 & 2,258 & 679 & 922 & 666 & 926 \\
\hline $95^{\text {th }} \%$ & 2,864 & 4,272 & 2,662 & 3,767 & 1,022 & 1,625 & 954 & 1,483 \\
\hline $99^{\text {th }} \%$ & 8,073 & 15,457 & 7,043 & 12,135 & 2,635 & 5,768 & 2,335 & 4,665 \\
\hline \multicolumn{9}{|c|}{ Constant Relative Risk Aversion such that Indifferent Across Match Policy, Additional Uncorrelated Wealth (\$000s), Prefer Company Stock Match if CRRA $<X$} \\
\hline & $\begin{array}{c}\text { Choice Firm } \\
\text { (choice vs. co. stock) }\end{array}$ & $\begin{array}{r}\text { Co. Sto } \\
\text { (choice vs }\end{array}$ & $\begin{array}{l}\text { k Firm } \\
\text { co. stock) }\end{array}$ & $\begin{array}{l}\text { o. Stock Firm vs. } \\
\text { Choice Firm }\end{array}$ & $\begin{array}{c}\text { Choice Firm } \\
\text { (choice vs. co. stock) }\end{array}$ & $\begin{array}{l}\text { Co. Stoc } \\
\text { (choice vs. }\end{array}$ & $\begin{array}{l}\text { k Firm } \\
\text { co. stock) }\end{array}$ & $\begin{array}{l}\text { o. Stock Firm vs. } \\
\text { Choice Firm }\end{array}$ \\
\hline 0 & 1.2 & 1 & & 1.8 & 0.8 & 1. & & 1.2 \\
\hline 250 & 1.6 & 2 & & 2.9 & 1.3 & $1 .($ & & 2.2 \\
\hline 500 & 2.0 & 3 & & 4.0 & 1.7 & 2.2 & & 3.1 \\
\hline 1000 & 2.7 & 4 & & 6.0 & 2.4 & 3. & & 4.9 \\
\hline
\end{tabular}

Source: Authors' calculations as described in text. 
Table 12: Distribution of 401(k) Plan Assets Assuming Workers Invest All Contributions in a Single Fund, by Match Policy

\begin{tabular}{|c|c|c|c|c|c|c|c|c|c|c|c|c|c|c|}
\hline & \multicolumn{2}{|c|}{$\begin{array}{c}\text { (1) } \\
\text { Company } \\
\text { Stock }\end{array}$} & \multicolumn{2}{|c|}{$\begin{array}{c}\text { (2) } \\
\text { Money } \\
\text { Market }\end{array}$} & \multicolumn{2}{|c|}{$\begin{array}{l}\text { (3) } \\
\text { Government } \\
\text { Bonds }\end{array}$} & \multicolumn{2}{|c|}{$\begin{array}{l}\text { (4) } \\
\text { Corporate } \\
\text { Bonds }\end{array}$} & \multicolumn{2}{|c|}{$\begin{array}{l}\text { (5) } \\
\text { Balanced } \\
\text { Fund }\end{array}$} & \multicolumn{2}{|c|}{$\begin{array}{c}\text { (6) } \\
\text { Large-cap } \\
\text { Equity Fund }\end{array}$} & \multicolumn{2}{|c|}{$\begin{array}{c}\text { (7) } \\
\text { Small-cap } \\
\text { Equity Fund }\end{array}$} \\
\hline & Choice & $\begin{array}{c}\text { Co. } \\
\text { Stock }\end{array}$ & Choice & $\begin{array}{c}\text { Co. } \\
\text { Stock }\end{array}$ & Choice & $\begin{array}{c}\text { Co. } \\
\text { Stock }\end{array}$ & Choice & $\begin{array}{c}\text { Co. } \\
\text { Stock }\end{array}$ & Choice & $\begin{array}{c}\text { Co. } \\
\text { Stock }\end{array}$ & Choice & $\begin{array}{c}\text { Co. } \\
\text { Stock }\end{array}$ & Choice & $\begin{array}{c}\text { Co. } \\
\text { Stock }\end{array}$ \\
\hline $\begin{array}{l}\% \text { times have } \\
\text { higher wealth }\end{array}$ & 10 & 90 & 42 & 58 & 32 & 68 & 42 & 58 & 48 & 52 & 41 & 59 & 78 & 22 \\
\hline \multicolumn{15}{|c|}{ Account Balance at Age $62(\$ 000$ s) } \\
\hline Mean & 824 & 694 & 150 & 331 & 196 & 362 & 210 & 371 & 247 & 397 & 354 & 467 & 812 & 770 \\
\hline $1^{\text {st }} \%$ & 11 & 17 & 129 & 101 & 101 & 90 & 116 & 100 & 93 & 78 & 59 & 54 & 41 & 43 \\
\hline $5^{\text {th }} \%$ & 22 & 32 & 135 & 109 & 120 & 110 & 136 & 120 & 118 & 103 & 86 & 82 & 70 & 74 \\
\hline $10^{\text {th }} \%$ & 31 & 45 & 138 & 114 & 132 & 124 & 148 & 133 & 135 & 121 & 108 & 104 & 96 & 99 \\
\hline $25^{\text {th }} \%$ & 62 & 85 & 144 & 129 & 155 & 151 & 171 & 161 & 171 & 159 & 160 & 157 & 174 & 174 \\
\hline $50^{\text {th }} \%$ & 153 & 186 & 150 & 163 & 187 & 200 & 203 & 209 & 224 & 226 & 257 & 262 & 359 & 345 \\
\hline $75^{\text {th }} \%$ & 459 & 524 & 156 & 275 & 227 & 315 & 241 & 324 & 297 & 374 & 425 & 479 & 793 & 760 \\
\hline $90^{\text {th }} \%$ & 1,319 & 1,327 & 162 & 543 & 271 & 582 & 283 & 594 & 387 & 670 & 692 & 885 & 1,731 & 1,604 \\
\hline $95^{\text {th }} \%$ & 2,634 & 2,307 & 165 & 871 & 302 & 906 & 312 & 917 & 456 & 1,002 & 941 & 1,282 & 2,809 & 2,532 \\
\hline $99^{\text {th }} \%$ & 10,478 & 8,166 & 172 & 2,825 & 373 & 2,855 & 378 & 2,880 & 625 & 3,024 & 1,682 & 3,423 & 7,359 & 6,927 \\
\hline \multicolumn{15}{|c|}{ Constant Relative Risk Aversion such that Indifferent Across Match Policy, Additional Uncorrelated Wealth (\$000s) } \\
\hline & \multicolumn{2}{|c|}{\begin{tabular}{|c|} 
Prefer co. \\
stock match if \\
CRRA $>X$ \\
\end{tabular}} & \multicolumn{10}{|c|}{ Prefer company stock match if $C R R A<X$} & \multicolumn{2}{|c|}{$\begin{array}{c}\text { Prefer co. } \\
\text { stock match if } \\
\text { CRRA }>\text { X }\end{array}$} \\
\hline 0 & \multicolumn{2}{|c|}{0.4} & \multicolumn{2}{|c|}{4.4} & \multicolumn{2}{|c|}{3.8} & \multicolumn{2}{|c|}{3.1} & \multicolumn{2}{|c|}{2.2} & \multicolumn{2}{|c|}{2.1} & \multicolumn{2}{|c|}{1.8} \\
\hline 250 & \multicolumn{2}{|c|}{0.5} & \multicolumn{2}{|c|}{11.1} & \multicolumn{2}{|c|}{9.1} & \multicolumn{2}{|c|}{6.8} & \multicolumn{2}{|c|}{4.5} & \multicolumn{2}{|c|}{4.3} & \multicolumn{2}{|c|}{4.1} \\
\hline 500 & \multicolumn{2}{|c|}{0.6} & \multicolumn{2}{|c|}{17.8} & \multicolumn{2}{|c|}{14.4} & \multicolumn{2}{|c|}{10.5} & \multicolumn{2}{|c|}{6.7} & & & & \\
\hline 1000 & & & & & & & & & & & & & & \\
\hline
\end{tabular}

Source: Authors' calculations as described in text. It is assumed that when the match is unrestricted (i.e., choice), that the worker invests both employee and employer contributions in the one asset, and when the match is required to be in company stock, the employer contribution is invested in company stock, but the employee contribution is invested in the one asset. Simulations incorporate a reduction in the equity premium as well as bankruptcy risk. 
Appendix Table 1: Summary Statistics of Firm Characteristics by Match Policy, Full Sample

\begin{tabular}{|c|c|c|c|c|c|c|}
\hline \multirow[b]{2}{*}{ Variable (in percent) } & \multicolumn{3}{|c|}{ Mean } & \multicolumn{3}{|c|}{ Median } \\
\hline & $\begin{array}{l}\text { Match All } \\
\text { Co. Stock }\end{array}$ & $\begin{array}{l}\text { Match } \\
\text { Choice }\end{array}$ & Difference & $\begin{array}{l}\text { Match All } \\
\text { Co. Stock }\end{array}$ & $\begin{array}{l}\text { Match } \\
\text { Choice }\end{array}$ & Difference \\
\hline Defined Benefit Plan? & 68.3 & 44.0 & $24.3^{* * *}$ & 100.0 & 0.0 & $100.0^{* * *}$ \\
\hline Total Monthly Volatility & 9.3 & 10.2 & $-0.9^{* * *}$ & 8.2 & 9.5 & $-1.3^{* * *}$ \\
\hline Idiosyncratic Monthly Risk & 8.5 & 9.5 & $-1.0^{* * *}$ & 7.3 & 8.8 & $-1.5^{* * *}$ \\
\hline Market Beta & 0.86 & 0.88 & -0.02 & 0.86 & 0.87 & -0.01 \\
\hline Investment Grade Debt? & 48.9 & 30.2 & $18.8^{* * *}$ & 0.0 & 0.0 & 0.0 \\
\hline Cash Flow / Assets & 12.6 & 12.2 & 0.4 & 12.5 & 12.3 & 0.3 \\
\hline Is Cash Flow/Assets $<0 ?$ & 3.5 & 3.5 & -0.1 & 0.0 & 0.0 & 0.0 \\
\hline Cash Flow / Assets (if $>0$ ) & 14.0 & 13.0 & 1.0 & 12.9 & 12.5 & 0.4 \\
\hline Cash Flow / Assets $($ if $<0)$ & -26.7 & -11.0 & -15.7 & -8.8 & -6.6 & -2.2 \\
\hline Pay Dividends? & 70.6 & 57.5 & $13.1^{* * *}$ & 100.0 & 100.0 & 0.0 \\
\hline Dividend Yield & 1.94 & 1.36 & $0.58^{* * *}$ & 1.57 & 0.63 & $0.94^{* * *}$ \\
\hline Market-to-Book Ratio & 1.68 & 1.73 & -0.06 & 1.30 & 1.33 & -0.03 \\
\hline Total Employees (000s) & 18.0 & 13.0 & 5.0 & 5.0 & 4.0 & $1.0^{* *}$ \\
\hline Multiple Classes of Stock? & 3.0 & 6.5 & $-3.5^{* *}$ & 0.0 & 0.0 & 0.0 \\
\hline Past 5-year stock return & 137.4 & 177.0 & $-39.5^{*}$ & 95.0 & 92.8 & 2.6 \\
\hline S\&P 500? & 35.0 & 21.9 & $13.1^{* * *}$ & 0.0 & 0.0 & 0.0 \\
\hline Firm Market Cap (\$ mil) & 4191 & 4258 & -67 & 1068 & 619 & $452^{* * *}$ \\
\hline Firm Assets (\$ mil) & 8261 & 6828 & 1433 & 1469 & 900 & $570^{* * * *}$ \\
\hline
\end{tabular}

${ }^{* * *},{ }^{* *},{ }^{*}$ denote difference is significant at the 1 percent, 5 percent, and 10 percent levels, respectively. 


\section{Appendix Table 2: Correlation of Firm Characteristics, Full Sample}

\begin{tabular}{|c|c|c|c|c|c|c|c|c|c|c|c|c|c|c|}
\hline & (1) & (2) & (3) & (4) & (5) & (6) & (7) & (8) & (9) & (10) & (11) & (12) & (13) & (14) \\
\hline (1) Match in company stock & 1.00 & & & & & & & & & & & & & \\
\hline (2) Defined Benefit Plan & $0.24^{* * *}$ & 1.00 & & & & & & & & & & & & \\
\hline (3) Monthly std. dev. of returns & $-0.11^{* * *}$ & $-0.41^{* * *}$ & 1.00 & & & & & & & & & & & \\
\hline (4) Investment grade debt? & $0.19^{* * *}$ & $0.39^{* * *}$ & $-0.43^{* * *}$ & 1.00 & & & & & & & & & & \\
\hline (5) Cash Flow-to-Assets & 0.02 & $0.10^{* * *}$ & $-0.07^{* * *}$ & $0.06^{* * *}$ & 1.00 & & & & & & & & & \\
\hline (6) Cash Flow-to-Assets (if $>0$ ) & $0.05^{* * *}$ & $0.06^{* * *}$ & $0.06^{* * *}$ & -0.01 & 1.00 & 1.00 & & & & & & & & \\
\hline (7) Cash Flow-to-Assets (if $<0$ ) & $-0.19^{* *}$ & 0.13 & $-0.20^{*}$ & 0.07 & 1.00 & NA & 1.00 & & & & & & & \\
\hline (8) Dividend Yield & $0.15^{* * *}$ & $0.33^{* * *}$ & $-0.56^{* * *}$ & $0.35^{* * *}$ & -0.02 & $-0.12^{* * *}$ & 0.11 & 1.00 & & & & & & \\
\hline (9) Market-to-book ratio & -0.02 & $-0.08^{* * *}$ & $0.13^{* * *}$ & $-0.04^{* *}$ & $0.31^{* * *}$ & $0.61^{* * *}$ & $-0.21^{* *}$ & $-0.21^{* * *}$ & 1.00 & & & & & \\
\hline (10) Log (Employees) & $0.07^{* * *}$ & $0.38^{* * *}$ & $-0.34^{* * *}$ & $0.45^{* * *}$ & $0.20^{* * *}$ & $0.04^{* *}$ & $0.46^{* * *}$ & $0.14^{* * *}$ & -0.01 & 1.00 & & & & \\
\hline (11) Multiple classes of stock? & $-0.08^{* * *}$ & $-0.07^{* * *}$ & 0.02 & $-0.06^{* * *}$ & -0.00 & -0.03 & 0.06 & $-0.08^{* * *}$ & -0.03 & 0.00 & 1.00 & & & \\
\hline (12) Past 5-year stock return & $-0.05^{* * *}$ & $-0.15^{* * *}$ & $0.15^{* * *}$ & 0.00 & $0.13^{* * *}$ & $0.13^{* * *}$ & 0.02 & $-0.14^{* * *}$ & $0.30^{* * *}$ & $0.05^{* *}$ & 0.03 & 1.00 & & \\
\hline (13) S\&P 500? & $0.14^{* * *}$ & $0.35^{* * *}$ & $-0.32^{* * *}$ & $0.52^{* * *}$ & $0.12^{* * *}$ & $0.11^{* * *}$ & 0.07 & $0.21^{* * *}$ & $0.11^{* * *}$ & $0.60^{* * *}$ & $-0.07^{* * *}$ & 0.00 & 1.00 & \\
\hline (14) Log (Assets) & $0.10^{* * *}$ & $0.42^{* * *}$ & $-0.50^{* * *}$ & $0.59^{* * *}$ & 0.01 & $-0.22^{* * *}$ & $0.53^{* * *}$ & $0.36^{* * *}$ & $-0.13^{* * *}$ & $0.72^{* * *}$ & $-0.03^{* *}$ & $0.04^{* *}$ & $0.60^{* * *}$ & 1.00 \\
\hline
\end{tabular}

${ }^{* * *},{ }^{* *},{ }^{*}$ denote significance at the 1 percent, 5 percent, and 10 percent levels, respectively. 